\title{
Lithostratigraphy of the Mesoproterozoic Vemork formation, central Telemark, Norway
}

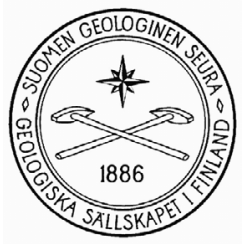

\author{
Kauko Laajoki ${ }^{1 * *}$ and Fernando Corfu ${ }^{2)}$ \\ 1) Department of Geosciences, University of Oulu, P.O. Box 3000, 90014 University of Oulu, \\ Finland \\ 2) University of Oslo, Department of Geosciences, Postbox 1047 Blindern, N-0316 Oslo, Norway
}

\section{Abstract}

The Vemork formation forms a c. $2 \mathrm{~km}$ thick volcanic-sedimentary unit above the 1510 I 500 Ma old Tuddal felsic volcanite formation, the oldest unit of the Mesoproterozoic Telemark supracrustals in southern Norway. It is dominated by basaltic metalavas with sedimentary interunits of variable thicknesses. Its lower contact with the majorTuddal volcanite body is considered conformable, but an angular unconformity is also possible. The change from the felsic Tuddal volcanism to the basaltic Vemork volcanism is interbedded as the flow-banded Skardfoss and Homvatnet metarhyolite members occur in the lower part of the Vemork formation. Zircon U-Pb dating of the Skardfoss metarhyolite constraints the beginning of deposition of the Vemork formation at around $1495 \pm 2$ Ma. In the north, the Vemork basalts are overlain by volcaniclastic arkosite and quartzites of the Vindeggen group, whereas in the south the Venutan member of diverse felsic volcanite rocks occupies the uppermost part of the Vemork group. It is mingled with the Vemork basalts, but seems to pass via a felsic vocaniclastic conglomerate and arkosites to the Gausta quartzite of the Vindeggen group.

Because of the Sveconorwegian deformation and metamorphism and uneven outcrop distribution individual Vemork units cannot be followed laterally for any longer distances and vertical sections are incomplete. Consequently, the lithostratigraphy for the Vemork formation can be established only tentatively. In the Froystaul type section, the $2 \mathrm{~km}$ thick sequence comprises at least 10 basaltic units separated by epiclastic units with variable amounts of both felsic and mafic volcanic material.

The nature of the upper boundary of the Vemork formation with the quartzite-dominated $V$ indeggen group is problematic as the rocks within the contact zone are intensely foliated and mostly unexposed. Sudden dying of volcanism and input of extrabasinal epiclastic material into the lower part of the Vindeggen group indicate that a significant tectonic change took place at the VemorkNindeggen boundary.

Key words: metavolcanic rocks, metasedimentary rocks, lithostratigraphy, structural geology, Proterozoic, Mesoproterozoic, Vemork, Telemark, Norway

*Corresponding author e-mail: kauko.laajoki@oulu.fi 


\section{Introduction}

Central Telemark in southern Norway is known for the rather well-preserved Mesoproterozoic volcanicsedimentary belt named collectively as Telemark supracrustals (Sigmond et al., 1997). Brief outlines and complexity of their geology have been known since Dons' (1960a, b) classical works. He included the lower volcanic part to the Rjukan group, which was subdivided into the Tuddal formation and the overlying Vemork formation. The former consists mainly of felsic volcanites, whereas the latter is dominated by basaltic volcanites with sedimentary interunits. The lithostratigraphy of the Vemork formation was not, however, studied in detail, whereas the geochemistry of its volcanites has been studied by Brewer (1985), Brewer \& Atkin (1987, 1989), Menuge \& Brewer (1996). Recent mapping has shown that the Vemork formation contains several units which could be mapped as individual formations and so it should be renamed and treated as a group of its own or as a subgroup of the Rjukan group (Nystuen, 1986; 1989). For practical reasons, however, the old usage is used in this paper and all the distinctive units named within the Vemork formation are treated as informal members.

The main purpose of the paper is to subdivide the c. $2 \mathrm{~km}$ thick Vemork formation with the aid of sedimentary units into smaller lithostratigraphic entities and to discuss its relationship with the Tuddal formation and the Vindeggen group. As the units are poorly exposed, metamorphosed and often pervasively foliated lithologies of the sedimentary and volcanic rocks can be described only briefly. For simplicity's shake, meta-prefix will not be used systematically in the rock names. The term "volcaniclastic" is used descriptively and applies to deposits composed of significant amounts of volcanic particles (Fischer, 1961). Because the petrography of the sedimentary units of sand grain size were studied only in some cases, sandstone is used as a general field name for them instead of quartzite (Dons et al., 2004, cf. Howard, 2005).

\section{Geological setting and regional lithostratigraphy}

The study area belongs to the Mesoproterozoic (c. 1.5 $\mathrm{Ga}$ to $<1.12 \mathrm{Ga}$ ) sedimentary-volcanic Telemark supracrustal belt (Sigmond et al., 1997), which occupies the northern part of the Sveconorwegian Telemark sector (Bingen et al., 2005) or block (Andersen, 2005) of the Southwest Scandinavian Domain (Gaál \& Gorbatschev, 1987) of the Fennoscandian (Baltic) Shield (Fig. 1). The c. $10 \mathrm{~km}$ wide Mandal-Ustaos(et) fault zone (Sigmond, 1985) with the Kalhovd fault as its western limit (Figs. 2 \& 3, Dons et al., 2004) separates the Telemark sector from the Hardangervidda sector (Bingen et al., 2005). In contrast to most of the metamorphic Precambrian crust in South Norway, the lithologies and stratigraphy of the Telemark supracrustals are relatively well preserved. The Telemark supracrustals comprise two major lithostratigraphic entities: the Vestfjorddalen (c. $1.5 \mathrm{Ga}$ to $<1.155 \mathrm{Ga}$ ) and Sveconorwegian (c. $1.155 \mathrm{Ga}-1.0 \mathrm{Ga}$ ) supergroups separated by the sub-Svinsaga unconformity (Fig. 2, Laajoki, in press).

The Vestfjorddalen supergroup forms the core of the Telemark belt and comprises two groups (Fig. 2): (1) the Rjukan group, which consists of (a) the Tuddal formation of c. $1.5 \mathrm{Ga}$ felsic volcanites (Dahlgren et al., 1990; Sigmond, 1998; Bingen et al., 2005), and (b) the c. $2 \mathrm{~km}$ thick volcanic-sedimentary Vemork formation with abundant metabasaltic units, and (2) the sedimentary Vindeggen group, c. $5 \mathrm{~km}$ thick, with several quartzite and two mudstone formations (Laajoki, in press). Only the basal arkosic-conglomeratic Heddersvatnet and the overlying quartzitic Gausta formations of the Vindeggen group are represented in the legend of Fig. 2, as they are essential for the understanding of this paper. In the Heddersvatnet area, the Vemork formation is missing and the Heddersvatnet formation lies directly on the Tuddal formation from which it seems to be separated by an angular unconformity (Laajoki, 2005). West of the Gausdalen fault (Fig. 3), pebbly and lithic quartzites of the Gausta formation overlie the Vemork formation from which it is separated by deformed volcaniclas- 
tic sandstones. This contact is treated more closely in section 9.1 .

The c. 1.15 - 1.1 Ga Sveconorwegian supergroup rims the Vestfjorddalen supergroup in the west, south and east. It includes the Oftefjell (oldest, Laajoki, 2006c) and Høydalsmo groups and the Eidsborg formation (youngest) in the southwest and west, the $1155 \pm 2 \mathrm{Ma}$ old Brunkeberg formation (Laajoki et al., 2002) and the overlying Lifjell group (Laajoki, 2006a, b) in the south and the $<1121 \pm 15 \mathrm{Ma}$ old Heddal group (Bingen et al., 2003) in the east (Fig. 2).

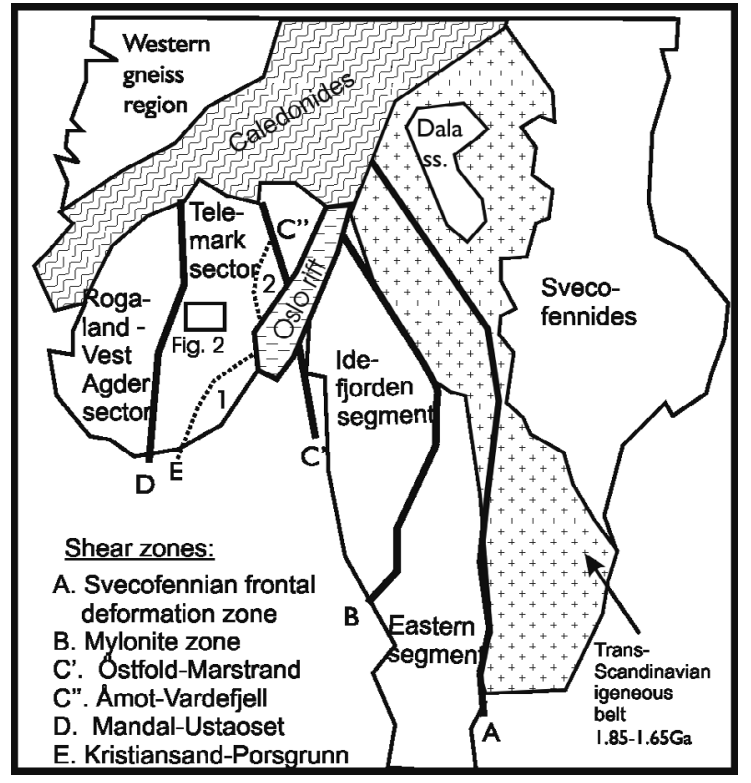

Fig. I. Sketch map of the Sveconorwegian province (modified from Bingen et al., 200 I). The area of Fig. 2 is framed. Numbered sectors west of the Oslo rift: (I) Bamble, (2) Kongsberg.

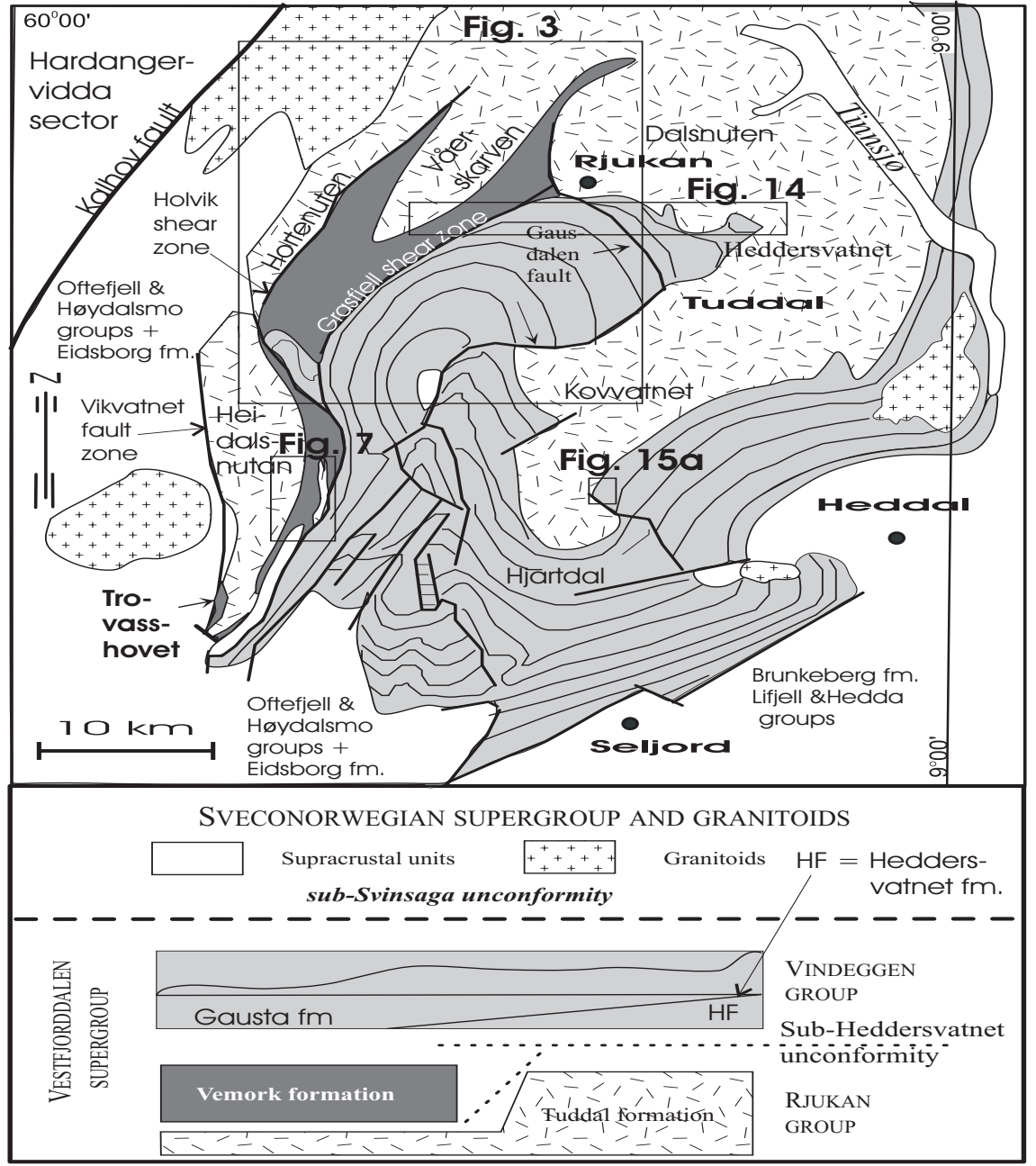

Fig. 2. Simplified geological map of the southern part of the Telemark supracrustals (in part after Dons \& Jorde, 1978). Areas of Figs. $3,7 \& 15 \mathrm{a}$ and the schematic cross section in Fig. 14 are framed. 


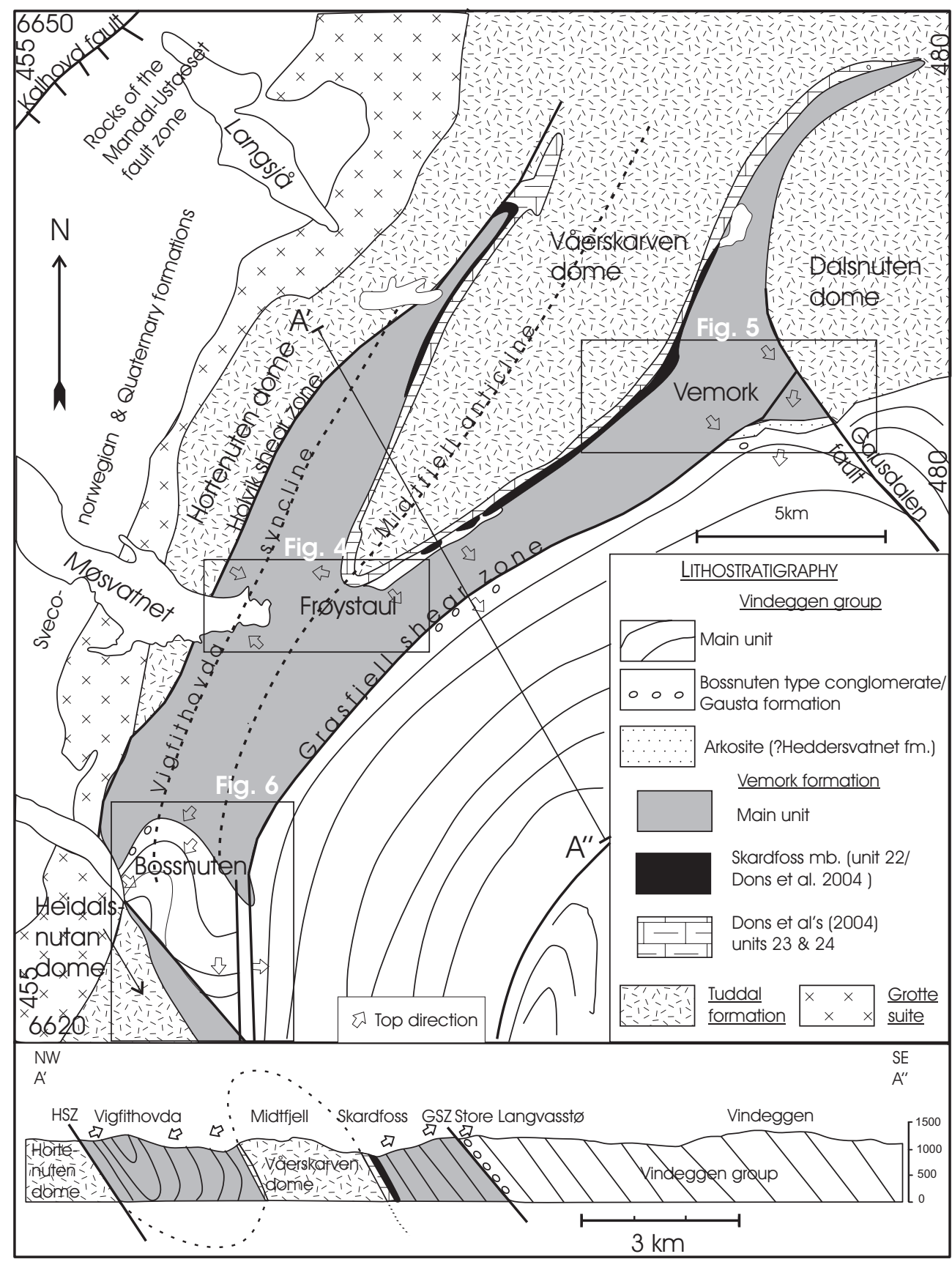

Fig. 3. Geological map of the Vemork-Møsvatnet area (modified from Dons, $196 \mathrm{I}$ and Dons et al., 2004, metadiabases omitted) and cross section (arrows indicate the top direction) across the Midtfjell anticline (modified from Dons et al., 2004). GSZ \& HSZ = Grasfjell and Holvik shear zones, respectively. Areas of Figs. $4-6$ are framed. 


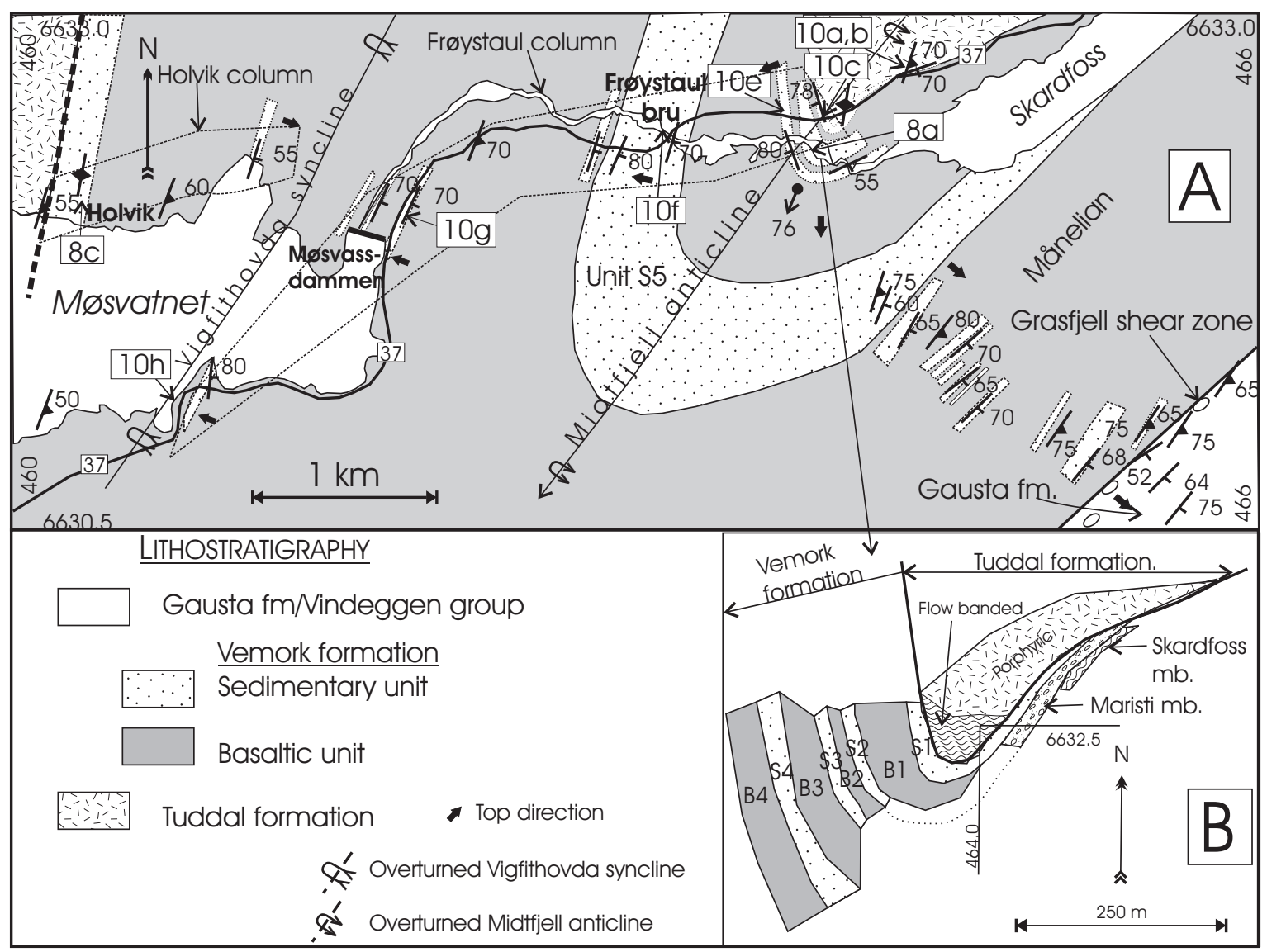

Fig. 4. a) Incomplete geological map of the Frøystaul area mapped along road 37 and across Månelian to the Grasfjell shear zone. Sections, along which the lithostratigraphic columns in Fig. 9 were established, are framed. Thicknesses of the sedimentary units in the Månelian section are exaggerated. b) a close-up map around the SW tip of the Våerskarven dome (thicknesses approximated). SI - S5 = Vemork sedimentary units I - 5. BI - B4 = Vemork basaltic units I - 4. Locations of photographed outcrops in Figs. 8a, c \& 10 are indicated by their numbers in white boxes.

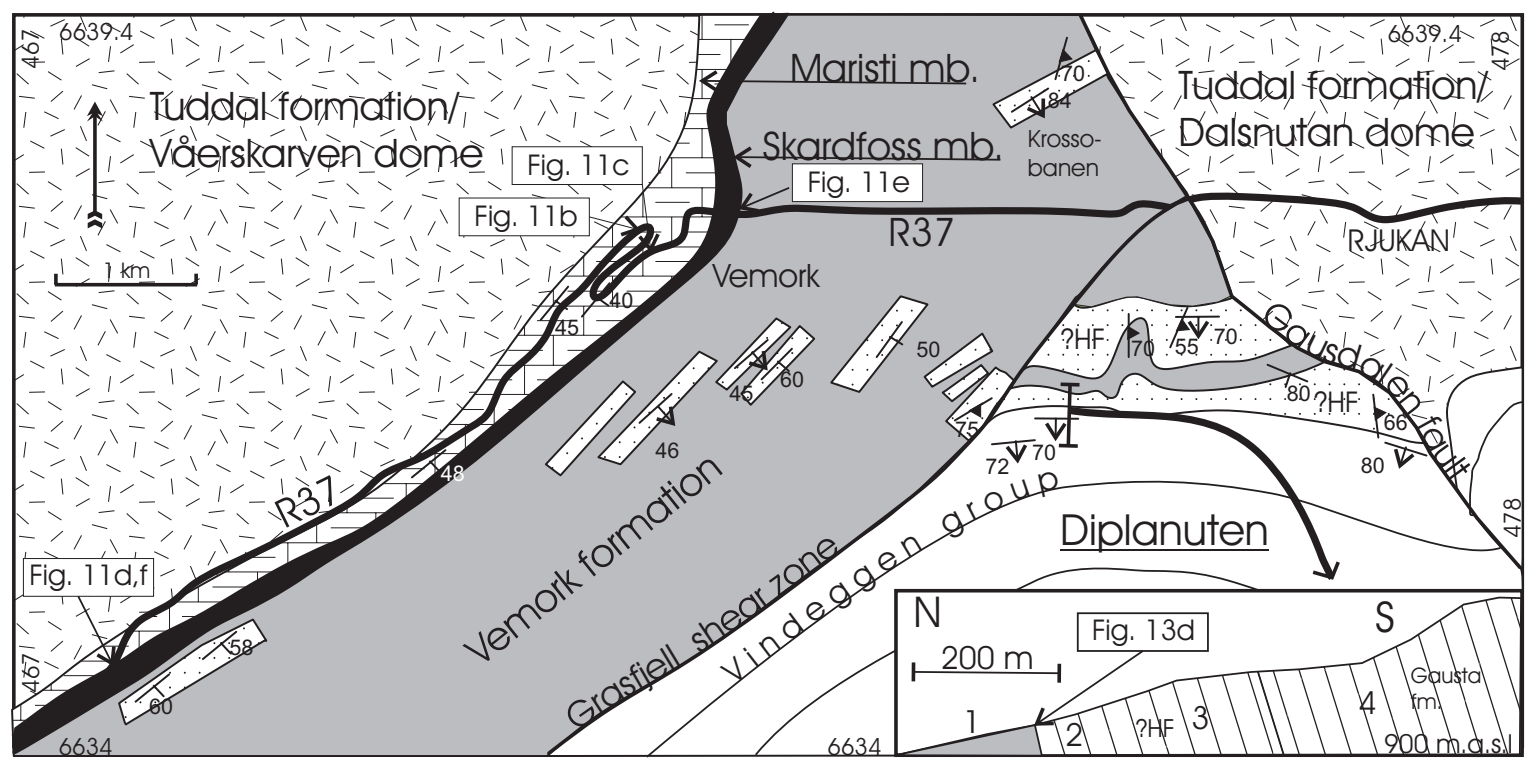

Fig. 5. Geological map of the Vemork area. Note the distribution of the Maristi (brick pattern) and Skardfoss (in black) members. ?HF = likely Heddersvatnet formation. Units in the cross section across the Vemork-Gausta contact zone (inset): I. Topmost Vemork metabasalt (Fig. I3d). 2. Biotitic sandstone. 3. Arkosite-sericite quartzite. 4. Gausta quartzite. Locations of Figs. I Ib-f and I3d are shown. For symbols see Fig. 6. 


\section{Previous lithostratigraphic and structural studies}

Wyckoff (1934) described some of the sedimentary rocks from Vestfjorddalen, which Dons (1960a, b, 1961) included into his Vemork formation. According to Dons (1960a, b) the Vemork formation rests conformably on the Tuddal formation and consists predominately of green lavas, which locally attain great thicknesses, tuffs, biotite schists and pebbly arkoses which, in places, grade into quartzites. The small porphyry occurrence in the Venutan area (section 8.5) has been included into the Tuddal group by previous authors (Dons 1961; Neumann \& Dons, 1961; Dons \& Jorde, 1978; Dons, 2003). Brewer (1985) stated that the Vemork formation rests unconformably (disconformably, Brewer \& Menuge, 1998) on the Tuddal formation and has a small metabasaltic flow at the base, which is overlain by a thick conglomeratic sequence with predominantly basaltic clasts. The conglomerate passes upwards into an interbedded sequence of cross-bedded sandstones and basic lavas. The upper part of the formation is dominated by metabasalts with intercalations of siltstone. Various ideas presented in the literature of the nature of the upper contact of Vemork formation are discussed in section 9.1.

The metabasalts have gone through (1) burial metamorphic epidotization, which affected especially the flow tops, and K-metasomatism producing muscovite and (2) greenschist facies regional metamorphism leading to destruction of the vast majority of the primary textures and replacement of the primary anhydrous mineral assemblages by extremely heterogeneous hydrous metamorphic assemblages (Brewer \& Atkin, 1987; 1989). The Vemork metabasalts have a within-plate chemical signature with major and trace element patterns similar to those of Phanerozoic continental flood basalts (Menuge \& Brewer, 1996; Brewer \& Atkin, 1989).

The structure of the Vemork formation has previously been treated only briefly (Dons, 1960a, b; Brewer \& Field, 1985; Brewer \& Atkin, 1987; Menuge \& Brewer, 1996; Starmer, 1993). Richards (1998) pos- tulated that the Vemork formation in the Frøystaul area was folded along the same N-S trending fold axis as the Seljord (Vindeggen) group in the core of his $\mathrm{D}_{4}$ Bossnuten synform (cf. Fig. 6). In a cross section presented by Dons et al. (2004), the Vemork formation forms two synclines that are overturned to the NW separated by an anticline cored by the Tuddal formation exposed in Midtfjell (cf. cross section in Fig. 3).

Geological maps available of the Vemork formation include the 1:100 000 map by Dons (1961) showing outcrop distribution of the main part of the formation, the 1:100 000 map by Neumann and Dons (1961), the 1:250 000 map by Dons and Jorde (1978) and the recent 1:50 000 map sheets of Amotsdal (Dons 2003) and Frøystaul (Dons et al. 2004), of which the last named covers most of the type area of the Vemork formation.

\section{Distribution and structural fea- tures of the Vemork formation}

The Vemork formation forms a c. $50 \mathrm{~km}$ long, NNE trending belt from Rjukan in the NE to Trovasshovet in the SW (Fig. 2). Dons (2003) correlated some of the basic lavas around Lake Vikvatnet (north of Trovasshovet in Fig. 2) with the Vemork formation, but since they as a whole or part of them may belong to the Oftefjell group (Laajoki \& Lamminen, 2006) they will not be treated in this paper. For simplicity's sake, the Tuddal formation underlying the Vemork formation is subdivided structurally into Vårskarven, Dalsnuten, Kovvatnet, Heidalsnutan, and Hortenuten domes (Figs. $2 \& 3$ ) as they may represent primary volcanic complexes folded by the Sveconorwegian deformation. The two last named domes are intruded in their western parts by granodioritic-dioritic plutonic rocks of the Grotte suite (Fig. 3), which Dons et al. (2004) considered younger than the Tuddal formation, but older than the Vemork formation. Rangnhildstveit et al. (1994) determined a U-Pb zircon age of $1509+19 /-3$ to a tonalite-quartz diorite of this suite. These rocks lie, however, outside the present study area.

The key structure in understanding of the lithos- 


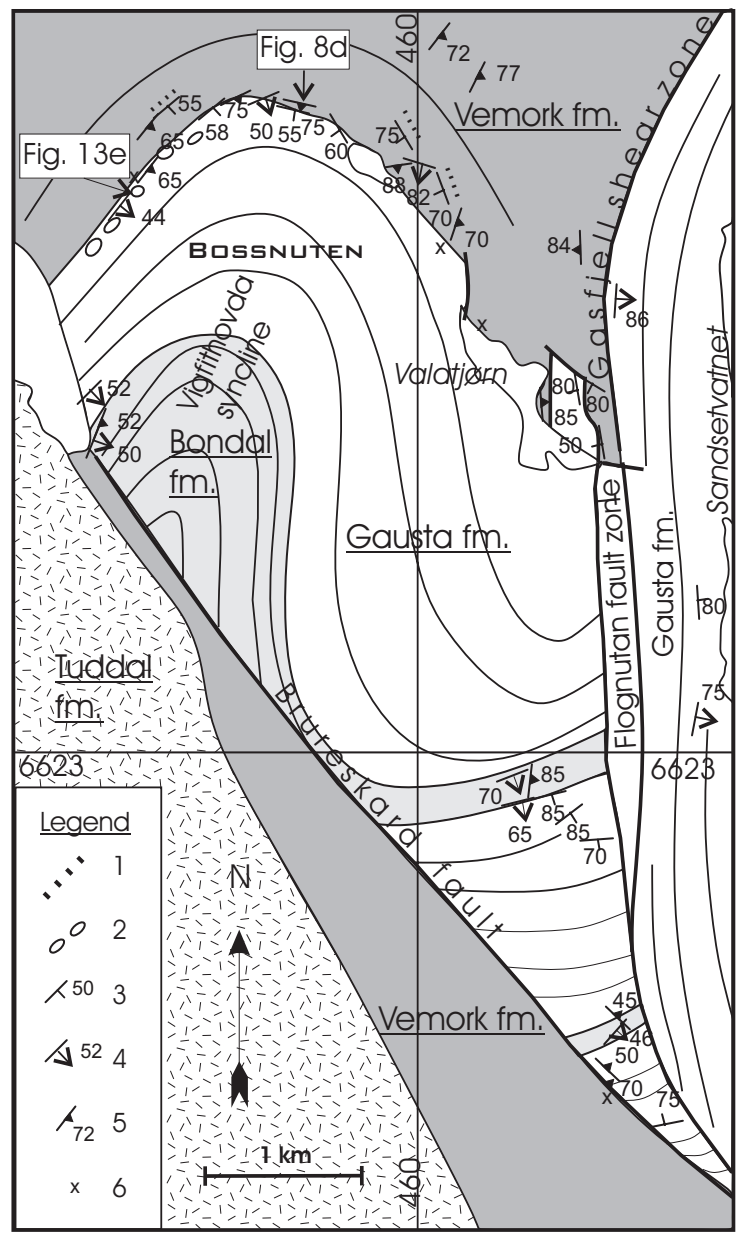

Fig. 6. Geological map of the Bossnuten area. Legend: (I) Sandstone interbed in the Vemork formation. (2) Bossnuten-type conglomerate of the Gausta formation. (3) Bedding and dip. (4) Bedding, dip, and top direction. (5) Foliation and dip. (6) Other outcrop observation. Form lines and thick lines indicate bedding trends and fault/ shear zones, respectively. Locations of Fig. $8 \mathrm{~d}$ and $13 \mathrm{e}$ are shown.

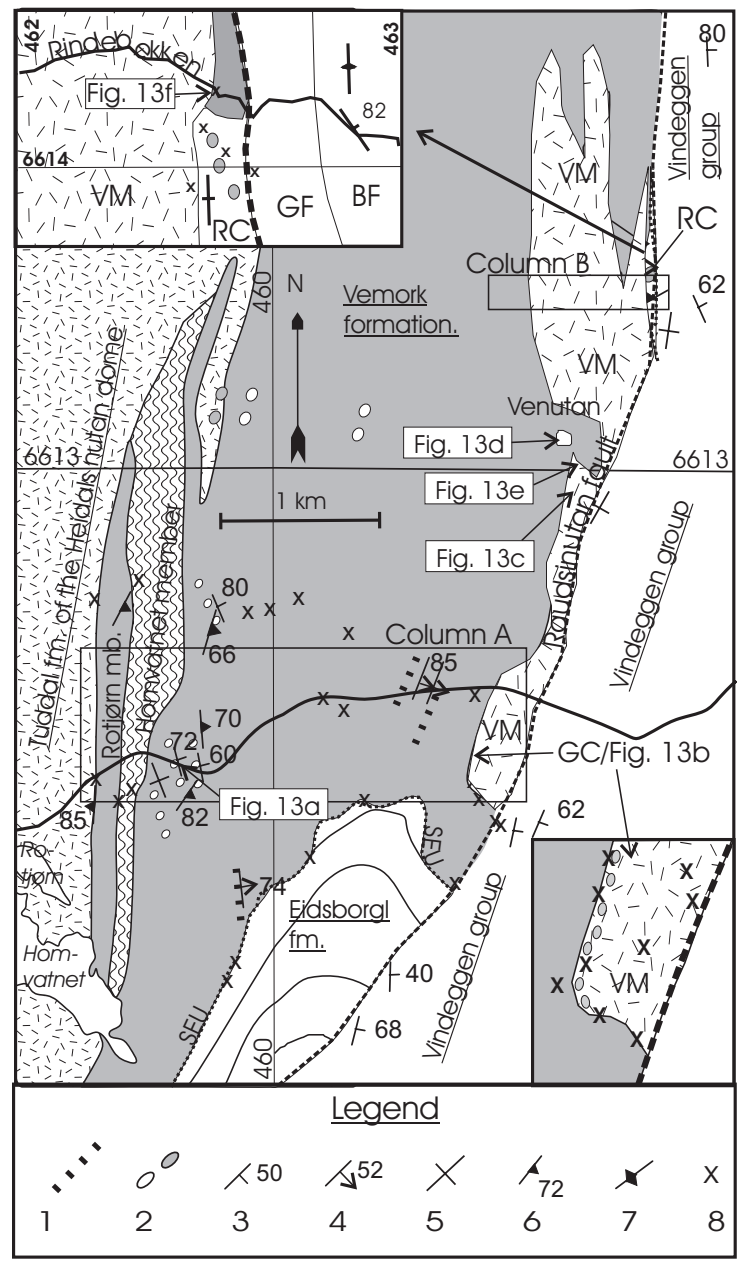

Fig. 7. Geological map of the Venutan area ( $N$ part after Dons, 2003). Lithostratigraphic units: BF, GF, GC, RC \& VM = Bondal and Gausta formations, Grovai and Rindebekken conglomerates, and Venutan member, respectively. SEU \& SRiU = sub-Eidsborg and sub-Rindebekken unconformities, respectively. Legend: (I) Sandstone interbed in the Vemork formation. (2) Conglomerate. (3) Bedding and dip. (4) Bedding, dip, and top direction (arrow head). (5) Vertical bedding (6) Foliation and dip. (7) Vertical foliation. (8) Other outcrop observation. Form lines in the Eidsborg formation indicate bedding trend. The areas used for construction of the stratigraphic columns $A$ \& B in Fig. 12 are framed and locations of Figs. I $3 a-f$ are shown. Upper (I km wide) and lower insets show details of the contact relationships in the Rindebekken and Grovåi areas, respectively. 
tratigraphy of the Vemork formation is the Våerskarven dome, which forms the core of the Midtfjell anticline (Figs. 3, 4). The lowermost parts of the Vemork formation are best accessible and preserved along the SE limb of the anticline, but the Gausdalen fault cuts them in the NE, where the formation abuts the Dalsnuten dome (Fig. 5). The nature of the upper contact of the Vemork formation with the Gausta formation is problematic (section 9) for it follows the Grasfjell shear zone (Fig. 3) or other faults (Fig. 6). The Vemork formation east of the Hortenuten dome is so strongly deformed that this is considered as a sheared limb of the Vigfithovda syncline bordered by the Holvik shear zone (Fig. 3). The part of the Vemork formation flanking the eastern margin of the Heidalsnutan dome (Figs. 3, 7) is autochthonous in relation to its Tuddal basement, but the Brureskard fault separates it from the main Vemork area (Fig. 6). Small parts of the formation occur also around the southern and eastern margins of the Heidalsnutan dome (Laajoki \& Lamminen, 2006).

The Vemork formation is a metamorphosed (greenschist-epidote amphibolite facies) volcanicsedimentary sequence, within which the dominating basaltic metalava/greenstone and tuffitic units are separated by sandstone-conglomerate units of variable thicknesses. It is impossible to subdivide the formation regionally into subunits as it is mostly unexposed, the metalavas have lost their primary features in most cases, and the sedimentary units separating metalava units cannot be followed for any greater distances. That is why the formation was studied in closer detail only in road cuts along the road 37 from Vemork to Møsvatnet (Figs. 4, 5) and in the Venutan area (Fig. 7). The upper contact was studied along the Grasfjell shear zone (Fig. 3), north of Bossnuten (Fig. 6), and at Diplanuten (Fig. 5).

\section{Lithostratigraphy of the Vemork formation in the Frøystaul - Møsvat- net area}

\section{I. Structural features}

The bedrock around the Frøystaul power station comprises the Midtfjell anticline overturned slightly to the NW (cross section in Fig. 3). The Tuddal formation of the Vårskarven dome occupies the core of the anticline rimmed by the Vemork formation. The axis of the anticline plunges $60^{\circ}-80^{\circ}$ to SSW (Fig. 8a). On the SE limb of the anticline, from Frøystaul to Vemork, the Vemork formation forms a sequence dipping steeply to the SE and younging towards the Gausta formation of the Vindeggen group (Fig. 4a), from which it is separated by the Grasfjell shear zone (Fig. 8b, cross section in Fig. 3, cf. Dons et al., 2004). East of Vemork, the Gausdalen fault cuts the Vemork formation (Figs. 3, 5). The portion north of Diplanuten, between the Grasfjell shear zone and the Gausdalen fault, is relatively well preserved and offers the only place where the likely primary upper contact of the Vemork formation has been found (Fig. 5).

The Vemork formation NW of the Midtfjell anticline forms the asymmetrical Vigfithovda syncline overturned slightly to the NW (cross section in Fig. 3 ). The lithological asymmetry of this syncline (columns A \& B in Fig. 9) and the strongly sheared Vemork formation conglomerates against the Hortenuten dome (Fig. 8c) indicate that the lower part of the formation has been cut off tectonically. This Holvik shear zone may be considered as the eastern limit of the Mandal-Ustaos fault zone whose western limit, the NE trending and about $35^{\circ}$ to the SE dipping Kalhovd fault, lies $20 \mathrm{~km}$ to the NE from Holvik (cross section in Dons et al., 2004).

Along the northern margin of Bossnuten (Fig. 6), c. $6 \mathrm{~km}$ to SW from Frøystaul, the Vemork formation dips under the Gausta formation of the Vindeggen group, but the contact is highly sheared (Fig. 8d) and may represent the folded and faulted extension of the Grasfjell shear zone (Fig. 6, cf. Richards, 1998).

\subsection{Lower contact of the Vemork formation}

Dons (1961) and Dons et al. (2004) laid the Tuddal formation /Vemork formation contact upon the flow-banded metarhyolite (unit f in Dons, 1961; unit 22 in Dons et al., 2004; the Skardfoss member in this study, Figs. 3 \& 5). Dons et al. (2004) includ- 
Table I. Lithostratigraphy of the Vemork formation along the Frøystaul section on the western limb of the Midtfjell anticline. For practical reasons, the sedimentary and basaltic metalava units are coded from bottom upwards $\mathrm{SI}, \mathrm{S} 2$ etc and BI, B2 etc, respectively. Polymictic conglomerates contain both felsic and mafic volcanite clasts. Sedimentary units dominantly of sand grain size are called simply sandstones or pebbly sandstones. Petrographic description for some of them can be found in the text.

\begin{tabular}{|c|c|c|c|}
\hline Unit & $\begin{array}{l}\text { Approx. } \\
\text { thickness } \\
(\mathbf{m})\end{array}$ & Lithology & Interpretation \\
\hline Total thickness & $>1975$ & & \\
\hline B10 & $>50$ & $\begin{array}{l}\text { Amygdaloidal in upper part massive metala- } \\
\text { va with thin epidotic sandstone interbeds (Fig. } \\
\text { 10h). Pillow lava-top breccias and fracture net- } \\
\text { works. }\end{array}$ & $\begin{array}{l}\text { Subaerial basalt, some of which flowed in } \\
\text { to water. }\end{array}$ \\
\hline $\begin{array}{l}\text { S10 } \\
\text { (Skinnarbu mb.) }\end{array}$ & 20 & $\begin{array}{l}\text { Lower part coarse, trough cross-bedded arko- } \\
\text { site with felsic vulcanite pebbles and dark slate } \\
\text { fragments. Middle part coarse sandstone with } \\
\text { mud layers and rip-ups. }\end{array}$ & Fluvial channel fill with overbank muds. \\
\hline B9 & 200 & Amygdaloidal metalava & Subaerial basalt \\
\hline S9 & 10 & Poorly exposed sandstone & \\
\hline$\underline{\mathrm{B} 8}$ & 30 & Amygdaloidal metalava & Subaerial basalt \\
\hline $\begin{array}{l}\text { S8 } \\
\text { (Møsvass- } \\
\text { dammen mb. 2) }\end{array}$ & 30 & $\begin{array}{l}\text { Pervasively foliated pebbly arkosite with dom- } \\
\text { inantly felsic volcanite and dark schist clasts. } \\
\text { Trough cross-bedded. }\end{array}$ & $\begin{array}{l}\text { Resembles lithologically the Holvik mem- } \\
\text { ber. }\end{array}$ \\
\hline B7 & 50 & Amygdaloidal metalava & Subaerial basalt \\
\hline $\begin{array}{l}\text { S7 } \\
\text { (Møsvass- } \\
\text { dammen mb. 1) }\end{array}$ & 40 & $\begin{array}{l}\text { Throughout trough cross-bedded sandstone } \\
\text { (Fig. 10g) }\end{array}$ & Fluvial sandstone \\
\hline B6 & 600 & Foliated amygdaloidal metalava & $\begin{array}{l}\text { Subaerial basalt. May contain sedimenta- } \\
\text { ry interunits }\end{array}$ \\
\hline S6 & 10 & $\begin{array}{l}\text { - Greenish, parallel-laminated rock }(1 \mathrm{~m}) \\
\text { - trough cross-bedded arkosite }(4.5 \mathrm{~m}) \\
\text { - granule-pebbly sandstone }(3 \mathrm{~m}) \\
\text { - tuffite }(1.7 \mathrm{~m}) \\
\end{array}$ & $\begin{array}{l}\text { A fining-upwards fluvial sequence be- } \\
\text { tween pyroclastic deposits }\end{array}$ \\
\hline B5 & 20 & Foliated amygdaloidal metalava & Subaerial basalt \\
\hline $\begin{array}{l}\text { S5 } \\
\text { (Frøystaul bridge } \\
\text { member) }\end{array}$ & 300 & $\begin{array}{l}\text { Laminated or trough cross-bedded arkosite- } \\
\text { sericite sandstone. Thin sandstone beds capped } \\
\text { by mudstone. In upper part polymictic vol- } \\
\text { caniclastic pebbly beds (Fig. 10f) and cross- } \\
\text { bedded beds. May contain volcanic interbeds. }\end{array}$ & $\begin{array}{l}\text { A complex fluvial - ?lake sequence, which } \\
\text { deserves to be studied in detail. }\end{array}$ \\
\hline B4 & 450 & Amygdaloidal metalava & $\begin{array}{l}\text { Subaerial basalt. Poorly exposed. Consists } \\
\text { most likely of several lava units separated } \\
\text { by thin sedimentary units not exposed. }\end{array}$ \\
\hline S4 & 50 & $\begin{array}{l}\text { Pebbly graded bedded sandstone overlain by } \\
\text { quartzitic sandstone (Fig. 10e). }\end{array}$ & Fluvial \\
\hline B3 & 40 & Amygdaloidal metalava & Subaerial basalt \\
\hline S3 & 5 & $\begin{array}{l}\text { Polymictic, matrix-supported pebbly conglom- } \\
\text { erate }\end{array}$ & Volcaniclastic debris flow \\
\hline B2 & 5 & Amygdaloidal metalava with tuffite interbeds. & $\begin{array}{l}\begin{array}{l}\text { Subaerial basalt and pyroclastic/epiclas- } \\
\text { tic interbeds }\end{array} \\
\end{array}$ \\
\hline S2 & 5 & $\begin{array}{l}\text { Matrix-supported polymictic conglomerate } \\
\text { overlain by sandstone (Fig. 10d) }\end{array}$ & $\begin{array}{l}\text { Volcaniclastic debris flow \& fluvial sand- } \\
\text { stone. }\end{array}$ \\
\hline$\underline{B} 1$ & 50 & Amygdaloidal metalava (Fig. 10d) & Subaerial basalt \\
\hline S1 & 10 & $\begin{array}{l}\text { Laminated, but foliated, greenish sandstone } \\
\text { (Fig. 10b). }\end{array}$ & $\begin{array}{l}\text { Note: on the E side of the anticline the } \\
\text { sandstone is overlain by a polymictic con- } \\
\text { glomerate, which may belong to the } \\
\text { Maristi member. }\end{array}$ \\
\hline Lower contact & - & Sharp, foliated (Fig. 10a). & Erosional \\
\hline
\end{tabular}




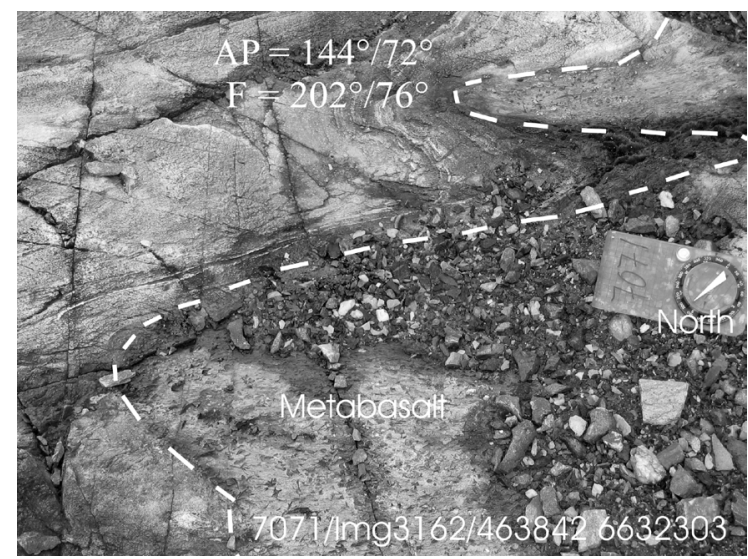

$8 \mathrm{a}$

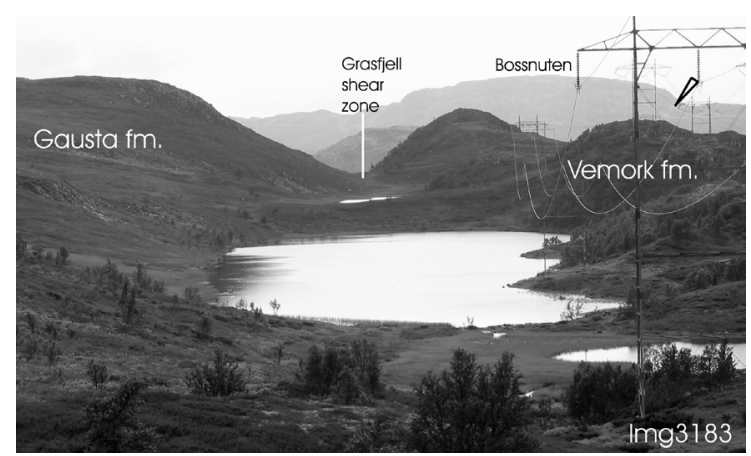

$8 b$

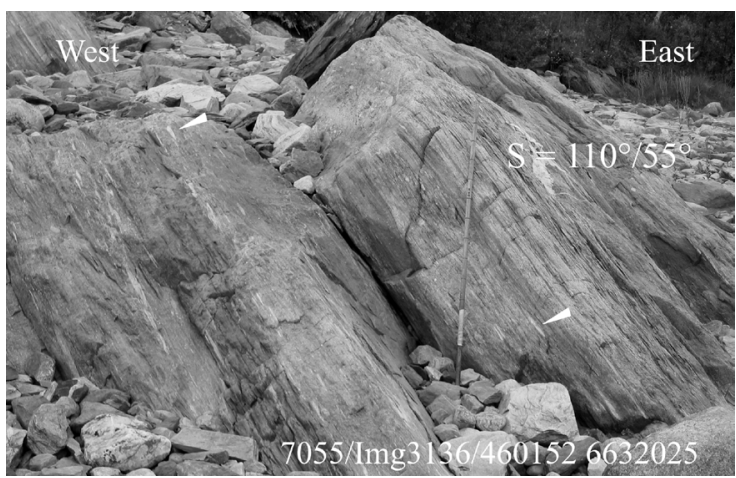

$8 c$

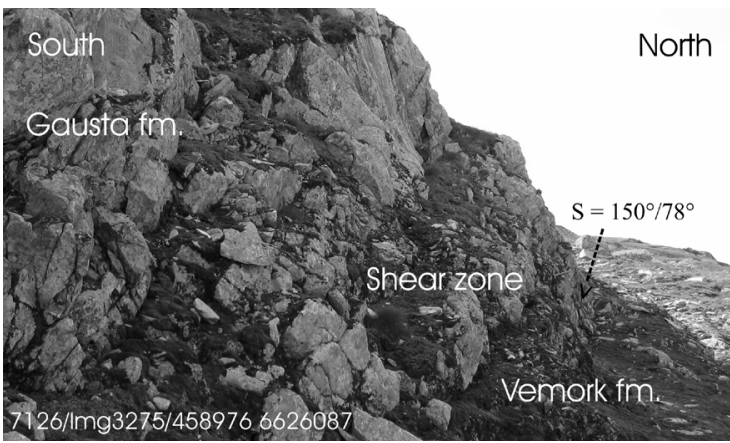

$8 d$

Fig. 8. Structural geological photographs of the Vemork formation. a) To the NW (towards the viewer) overturned minor folds in the Vemork formation reflecting the macrostructure of the Midtfjell anticline (cf. Wilson, 196I), Skardfoss. For locations see Fig. 4a. The plate of the compass used as a scale in this and other photographs is $6.5 \mathrm{x}$ $12 \mathrm{~cm}$. The number series in lower margins of photographs give station number, file number, and UTM coordinates. Structural abbreviations used in all the photographs: AP, F, S, \& $S_{0}=$ axial plane, fold axis, foliation, and bedding, respectively. b) View of the Grasfjell shear zone covered by the marshy terrain and ponds of the Litle Langvasstødalen valley. Seen from the NE. Arrow on the right upper corner points the sheared contact in Bossnuten displayed in Fig. 8d. c) Pervasively foliated volcaniclastic conglomerate. White arrows point to flattened and stretched felsic volcanite clasts. Holvik shear zone. For locations see Fig. 4a.The stick is $1.4 \mathrm{~m}$ long. d) Shear zone developed in a pervasively foliated and crenulated sericite schist-arkosite unit between a pervasively foliated Vemork greenstone (on the right) and a less deformed feldspathic quartzite of the Gausta formation, Bossnuten. For locations see Fig. 6. 
ed it and the underlying Maristi conglomerate (their unit 23) into the thin sedimentary-volcanic upper part of the Tuddal formation rimming the SW part of the Våerskarven dome (Fig. 3). The U-Pb zircon age of the Skardfoss rhyolite is $1495.6 \pm 2 \mathrm{Ma}$ (section 6.2), which is indistinguishable from the youngest age reported from the Tuddal formation $(1499 \pm$ $39 \mathrm{Ma}$, Sigmond \& Walker, in preparation; referred to by Dons et al. 2004) indicating that the Skardfoss member represents the last event of the Tuddal felsic volcanism. However, the Skardfoss member is underlain not only by the Maristi conglomerate, but also by a metabasalt, which may be considered as the first pulse of the Vemork basaltic volcanism. The transition from the Tuddal formation to the Vemork formation is thus interbedded. This and new observations in the Venutan area (section 7) support Dons' (1960a, b) concept that there is no significant unconformity between these formations and that they represent a single group (cf. Dahlgren et al. 1990). Being interbedded, it is a matter of agreement where the Tuddal/Vemork contact is laid. As the Skardfoss member is not a regional unit but ends at the SW end of Lake Skardfoss (Fig. 3, Dons et al. 2004), its upper surface is not a good reference surface and does not indicate any greater unconformity (section 6.2). Neither can the Maristi conglomerate be used for regional correlation. That is why the lower contact of the Vemork formation is laid above the coherent Tuddal domes, whose boundaries can be mapped regionally.

In Frøystaul, the lower contact lying below the first sedimentary unit ( 1 in Fig. 9) is exposed in a few road cuts at the SW tip of the Våerskarven dome. In the least deformed outcrop it is sharp, but pervasively foliated (Fig. 10a). The relict bedding in the overlying pebbly sandstone follows the contact, but as the Tuddal formation consists of a massive porphyry, no angular relationship between the rocks can be established. In other outcrops, either a pebbly sericite schist or a sericite sandstone lie directly on a flowbanded Tuddal rhyolite (Fig. 4b), but due to pervasive foliation the contact cannot be located exactly.

\subsection{Frøystaul-Møsvatnet section}

The map and lithostratigraphic column of the section of the Vemork formation along the road 37 from Frøystaul to Møsvatnet are given in Figs. 4a and 9, respectively. The section represents the slightly to the NW overturned limb of the Vigfithovda syncline. The sedimentary and basaltic units were coded with letters $S$ and B, respectively, and numbered from the bottom upwards. Their lithologies are summarized in Table 1. The total thickness of the sequence is about $2.2 \mathrm{~km}$ of which at least $70 \%$ consists of basaltic lavas. The basaltic units are monotonous consisting either of massive greenstones or amygdaloidal lavas. Some of the units are described below.

S1 (basal sedimentary unit): Unit S1 starts the Vemork formation. The part exposed at station 7046 consists of a conglomeratic sandstone, which contains only felsic volcanic clasts of pebble size or smaller and blue quartz-phenocryst and plagioclase clasts in a sericitic matrix (Fig. 10b). The volcanic material was most likely derived mainly from the underlying coarse porphyry, which also contains blue quartz indicating significant erosion of the porphyry before the extrusion of the first basalt flow (unit B1). When the unit $S 1$ overlies a flow-banded rhyolite, it consists of a greenish sericitic sandstone with plagioclase-phenocryst and glomerophyric plagioclase clasts or sericite schist (Fig. 10c).

$B 1$ (first basaltic unit): Unit B1 is an about $50 \mathrm{~m}$ thick amygdaloidal metalava unit with a chilled lower margin (Fig. 10c). Its upper part contains abundant stretched amygdules up to $10 \mathrm{~cm}$ long (Fig. 10d). The amygdules are filled with quartz of variable size and have a triformal-foam texture (Howard, 2005).

S2: This unit consists of an at least $5 \mathrm{~m}$ thick, fining-upwards sequence. It starts with a polymictic, matrix-supported conglomerate with both felsic and mafic cobbles in a mafic matrix (Fig. 10d). It contrasts the unit $S 1$, which contains only felsic clast material. The S2 mass-flow conglomerate resembles those in the Maristi member (section 6.1) with which it may be correlated, but the lack of outcrops leaves this question open. The conglomerate is overlain by 


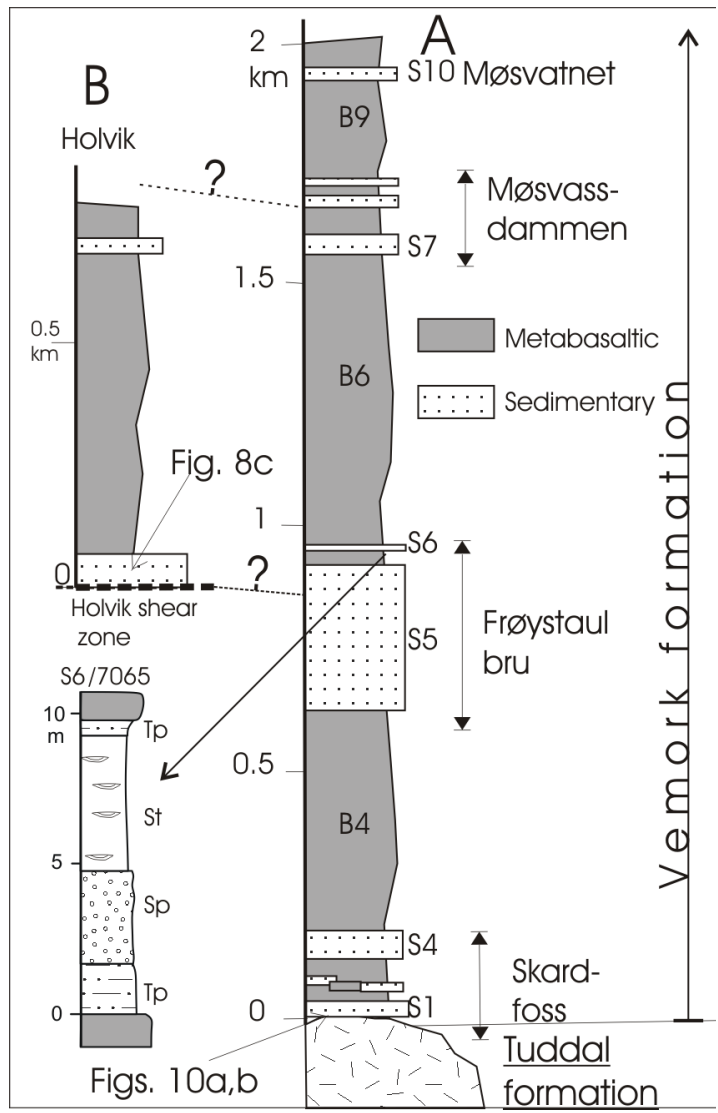

Fig. 9. Lithostratigraphic columns of the Frøystaul (A) and Holvik areas (B) (for locations see Fig. 4a and for correlation section 5.4 in the text) and the lithofacies column of unit S6. Lithofacies codes: St $=$ trough cross-bedded sandstone, $\mathrm{Sp}=$ pebbly sandstone, $\mathrm{Tp}=$ parallel laminated tuffite. Stratigraphic positions of Figs. $8 \mathrm{c}$ and $\mathrm{I0a}, \mathrm{b}$ are shown.

Fig. 10. Lithologies of the Vemork formation in the Frøystaul - Møsvatnet area. Outcrops in a-e \& g represent road cuts along road 37. For locations see Fig. 4a. a) Foliated contact zone between the Tuddal formation and the Vemork unit SI. For close up of the foliation see Fig. IOb. b) Close up of pervasively foliated Unit SI micaceous pebbly sandstone. Dark sericite-rich domains define the foliation (S). The lighter layers defining the transposed bedding $\left(\mathrm{S}_{0}\right)$ consisting of quartz- and plagioclase-phenocryst clasts and felsic volcanite clasts. c) Unit SI/Unit BI contact. Note parallel lamination in Unit SI quartzite and chilled margin and minor amygdales in Unit BI.Top to the west (left). d) Epidotized Unit BI/Unit S2 contact (left of the $1.4 \mathrm{~m}$ long stick). Note large quartz-filled vesicles in the upper part of the Unit BI lava (inset). Unit S2 starts with matrix-supported, polymictic conglomerate with both basic and felsic volcanic cobbles followed by quartzite (Qzte). Top to the west (left). e) Basal pebbly part of the Unit S4 overlain by quartzite (Qzte). Four mud topped graded pebbly beds are shown by white lines. The uppermost bed is $70 \mathrm{~cm}$ thick. Top to the west (left). f) Overturned graded beds with lower parts containing felsic volcanite pebbles and muddy upper parts. The stick is $1.4 \mathrm{~m}$. Frøystaul bru.g) Trough-cross bedded sandstone with solitary felsic volcanite pebbles. Unit S7, Møsvassdammen. h) A ?quench-fractured basaltic lava flow between thin, light-coloured epidotized sandstone layers. Unit BI0, Møsvatnet. Top down. 

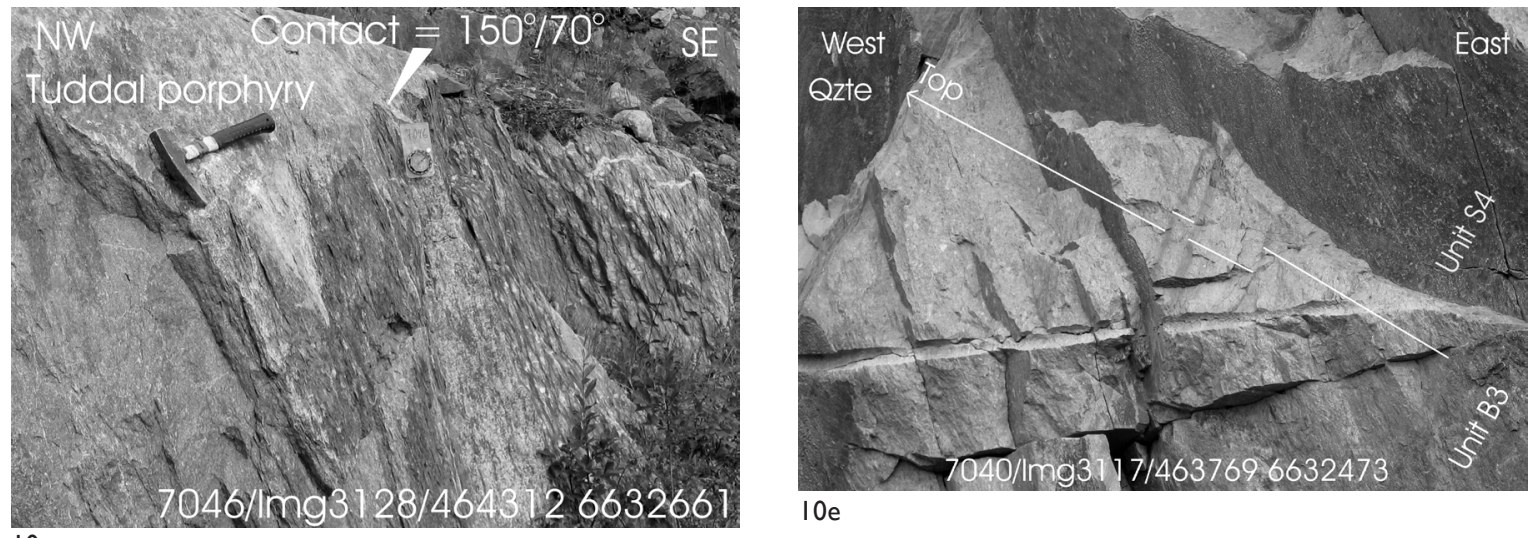

$10 \mathrm{a}$

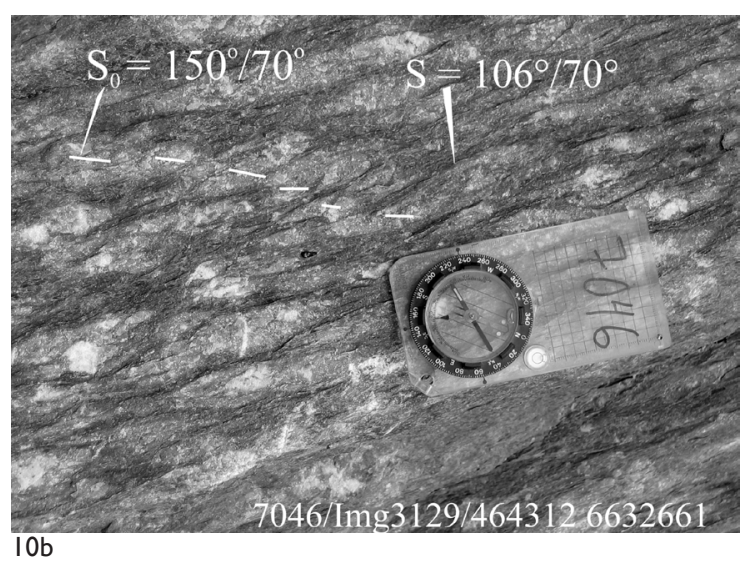

$10 \mathrm{e}$
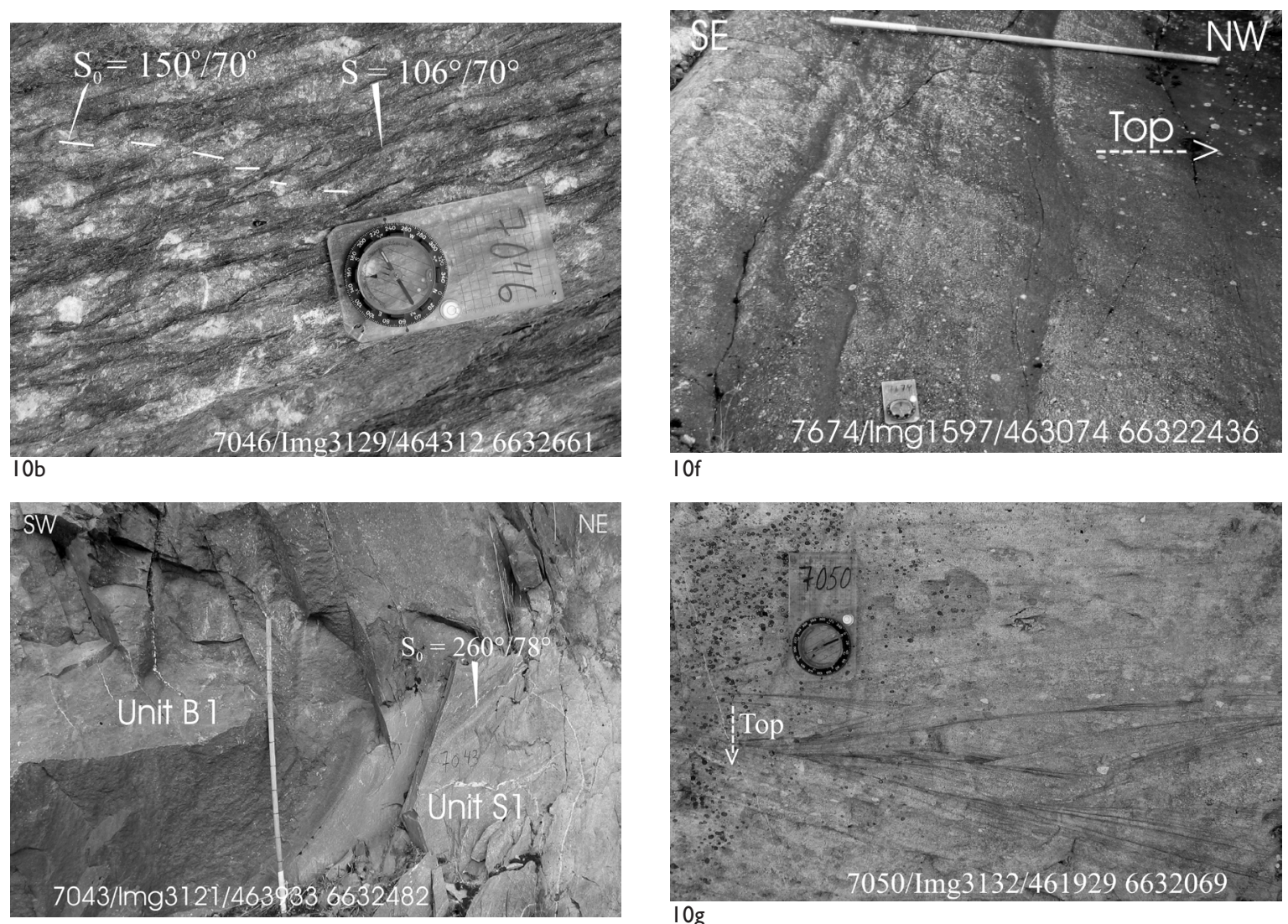
10c

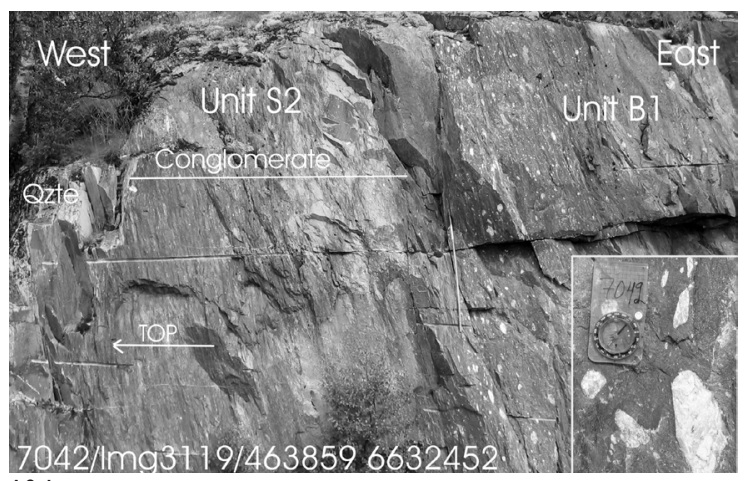

$\log$

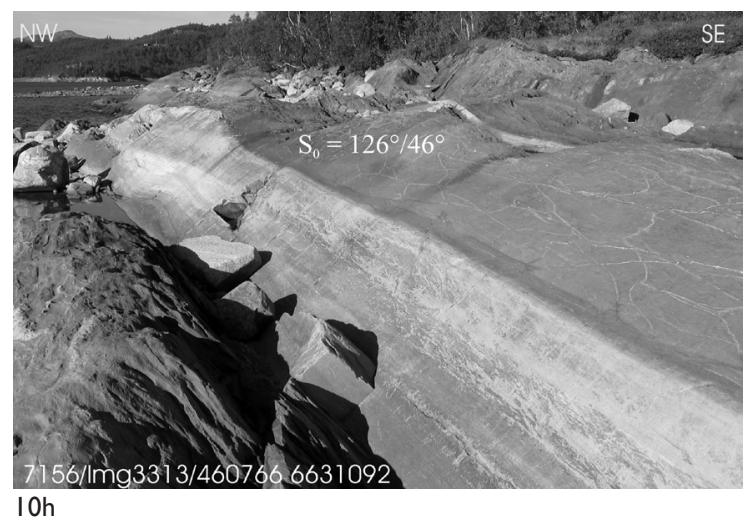


a sericite sandstone, of which, however, only a small portion is exposed (Fig. 10d).

S4: This unit, rather rich in epidote, represents a fining-upwards sequence starting with a pebbly part c. $1.2 \mathrm{~m}$ thick. The graded, mud-topped beds are up to $70 \mathrm{~cm}$ thick (Fig. 10e). Their pebbly parts contain abundant felsic volcanite clasts and triformal-foamtextured polycrystalline quartz grains. The latter represent amygdule clasts, for they are texturally identical to the quartz-filled amygdules studied from the basalt of the unit B1.

S5 (Froystaul bru member): This c. $300 \mathrm{~m}$ thick unit is well exposed in a river bed upstream from the Frøystaul bridge (bru), but the outcrops are stained by the river water. The member consists of diverse volcaniclastic sandstones, pebbly sandstones, some of which show turbiditic features (Fig. 10f), and pebbly conglomerates. A few tuffitic beds or even thin mafic lava flows may also occur. The sandstones studied are wackes with feldspar and Qp (amygdule) clasts in an epidote- and sericite rich matrix.

S6: This unit consists of a c. $10 \mathrm{~m}$ thick sequence of fining-upwards pebbly sandstone - trough crossbedded sandstone both overlain and underlain by tuffitic sandstone. Fig. 9 gives its detailed column.

S7 (Møsvassdammen member 1): This c. $40 \mathrm{~m}$ thick unit is characterised by trough cross-bedded fluvial sandstone with solitary felsic volcanite pebbles (Fig. $10 \mathrm{~g}$ ). The sandstone studied is a wacke with feldspar and Qp (amygdule) clasts in epidote- and sericite rich matrix.

$B 10$ (topmost lava unit): This unit comprises the poorly exposed uppermost part of this section. A good shoreline outcrop reveals that it consists of basaltic lava flows separated by thin epidotic sandstone beds (Fig. 10h).

In summary, the general sedimentological trend in the Frøystaul-Møsvatnet section is that coarser, polymictic mass-flow conglomerates occur only in the lower part of the formation, whereas the sedimentary units in the middle and upper parts consist mainly of graded - cross-bedded pebbly sandstones or cross bedded-parallel laminated sandstones and are relative- ly thin except unit S5. All the sandstone studied are both texturally and mineralogically immature being volcaniclastic wackes with abundant rock and mineral clasts both from felsic and mafic (amygdules) sources. Most of them are also relatively rich in epidote. Ubiquitous amygdules and lack of pillow structures in the metabasalts indicates that they were erupted subaerially. Consequently, the sedimentary interunits represent likely fluvial and shallow lake deposits, but their detailed facies analysis is left for future work.

\subsection{Holvik section}

This section north of Møsvatnet represents the western, sheared limb of the Vigfithovda syncline (Fig. 4a). As it is mostly forest-covered, only a schematic column can be given (column B in Fig. 9). The westernmost part is exposed on the shore outcrops near Holvik. The rocks are highly deformed, polymictic volcaniclastic cobble conglomerates and sandstones (Fig. 8c). Another sandstone unit occurs near the axial plane of the syncline. The area between these two sedimentary units seems to be underlain mostly by greenstones or amygdaloidal rocks. It is not possible to correlate this section on the basis of lithology with the Frøystaul - Møsvatnet section, but the geometry of the Vigfithovda syncline indicates that it represents the upper part of the Vemork formation (Fig. 9) cut by the Holvik shear zone.

\subsection{Månelian section}

The transect made across the forest-covered NW flank of the Månelian mountain represents the SE limb of the Midtfjell anticline (Fig. 4). The lower part of the section comprises the same units as the Frøystaul - Møsvatnet section, but the thick S5 member is exposed only in part. The middle and upper parts of the section consist of basaltic lavas with thin tuffitic and sandstone interunits. These cannot be readily correlated with the section in Møsvatnet. The section ends in the Litle Langvasstødalen valley, where the Grasfjell shear zone lies between the Vemork and 
Gausta formations (Fig. 8b). This contact is discussed in section 9.1 .

\section{Lithostratigraphy of the Vemork formation in the Vemork area}

Vemork, a historical industrial area in the Rjukan city, is located at the western end of the deep and steep Vestfjorddalen valley (Fig. 5). It contains two important members of the lower part of the Vemork formation, the Maristi and Skardfoss members, but the steepness of the valley walls (Fig. 11a) hampers detailed studies of the formation.

\section{I. Maristi conglomerate}

The Maristi conglomerate forms a narrow, c. $10 \mathrm{~km}$ long unit (Dons 1961) rimming the SE margin of the Våerskarven dome. Dons et al. (2004) described it as a conglomerate of assumed mud-flow origin with pebbles of metarhyolite and metabasalt. As the member dips parallel to the steep valley wall, its exact relationship to the Tuddal formation can not be seen, but it is likely separated from the latter by a thin sequence of Vemork basalts and sediments (cf. section 5.2).

The Maristi member, whose total thickness might be a few tens of meters, consists of up to a few metres thick matrix-supported conglomerates capped/ separated by thin $(<50 \mathrm{~cm})$ poorly laminated sandstone units. The size of the clasts varies from $1.5 \mathrm{~m}$ long boulders to pebbles (Figs. 11b, c). Both the bed thicknesses of and clast sizes in the conglomerate beds decrease upwards. In addition to diverse felsic volcanites, the conglomerates contain well-rounded, gray, intermediate biotite-plagioclase or muscovite-plagioclase metalavas pebbles and cobbles with blastotrachytic texture. Their provenance is not known. Large epidotized volcanite boulders are also distinctive (Fig. $11 \mathrm{~b})$. The dark matrix is rich in biotite and epidote and contains abundant plagioclase- and quartz-phenocryst clasts. Parallel laminated or cross-bedded sandstone beds were seen only in the upper part of the member. They are only a few tens of centimetres thick and may be draped by a thin mud layer. In agreement with Dons et al. (2004), the member is considered as a mass flow deposit, but its detailed study demands more sedimentological studies. The unit is thickest and coarsest in the NE indicating that the proximal area was situated in this direction.

\subsection{Skardfoss member}

Dons et al.'s (2004) flow-banded metarhyolite (their unit 22) is named informally the Skardfoss member after the artificial lake NE of which it is well exposed. The member is $20-50 \mathrm{~m}$ thick and consists solely of a flow-banded rhyolite (Fig. 11d). It erodes slightly the underlying micaceous sandstone-mica schist. Two types of a volcaniclastic breccia occur at the upper contact of the member. The first type occurs near Vemork, in the northeasternmost part of the member studied; see Brewer's (1985) Plate 2.1. Its breccia fragments have sharp and straight edges and do not show any preferred orientation. The jigsaw fit texture (Fig. 11e) and fragments free of quenching features indicate that the rock represents an autoclastic rather than a hyaloclastic breccia (McPhie et al., 1993). Its felsic matrix is rather rich in biotite-chlorite and the breccia passes to a greenish epidote-biotite-sericite schist. The second type occurs $2 \mathrm{~km} \mathrm{SW}$ of the first occurrence. It contains larger rhyolite fragments with roundish or curviplanar margins and clast groups with jigsaw fit in a matrix of smaller rhyolite fragments embedded in granoblastic quartz without any evidence of clastic origin (Fig. 11f). Flow banding in the parent lava can sometimes be traced continuously from clast to clast in adjacent in-situ breccia. These features point to a hyaloclastite (op. cit.).

Being syn-volcanic, the lava-top breccias described above are not a sign of any great unconformity. The presence of both autoclastic and hyaloclastic breccias indicates that the Skardfoss rhyolite extruded subaerially, but flowed into water and the flow direction was from the present NE to SW. The latter is in agreement with the palaeotopography indicated by the proximality of the Maristi member (section 6.1).

Zircons from the Skardfoss rhyolite were analyzed by ID-TIMS following the technique of Krogh 


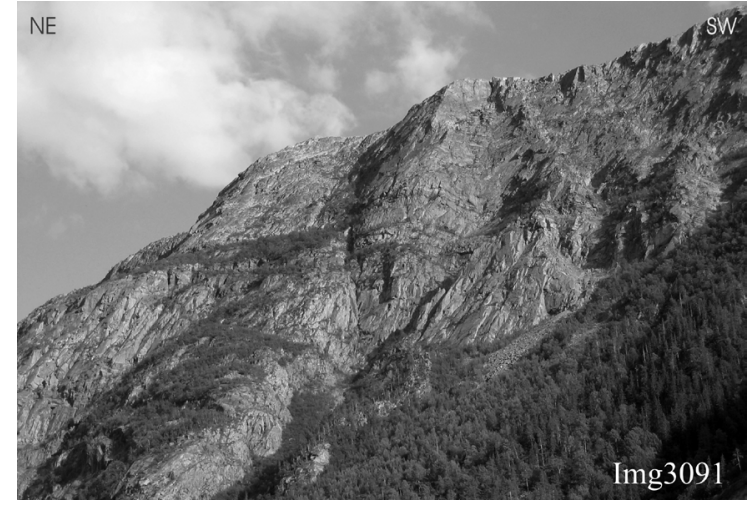

I la

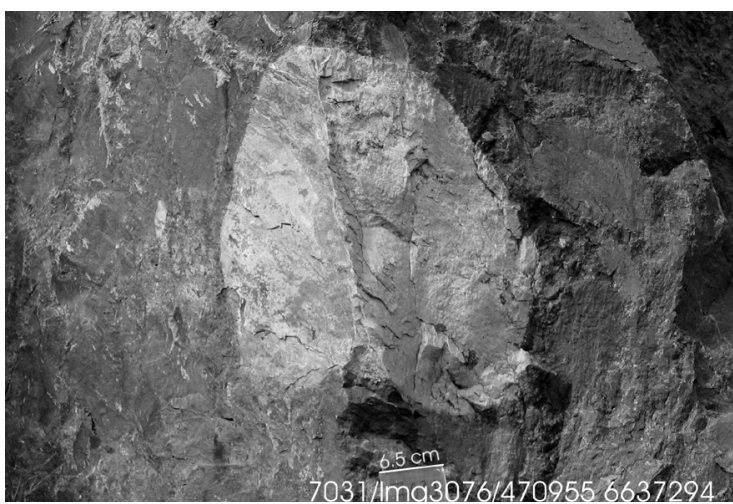

IIb

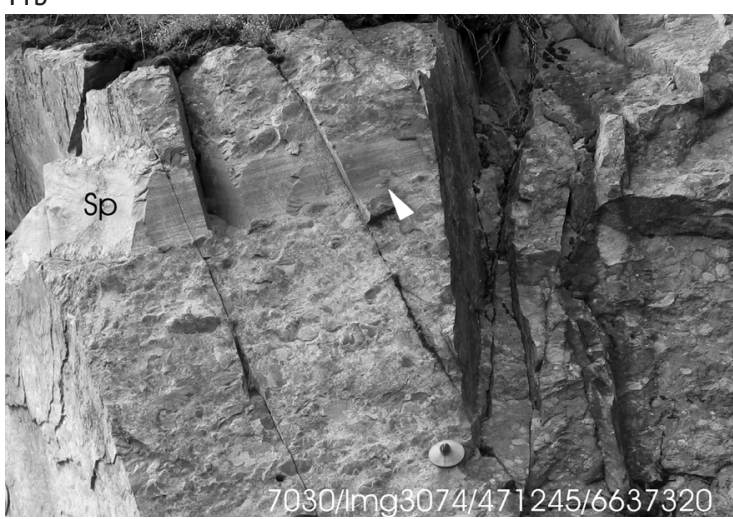

IIc

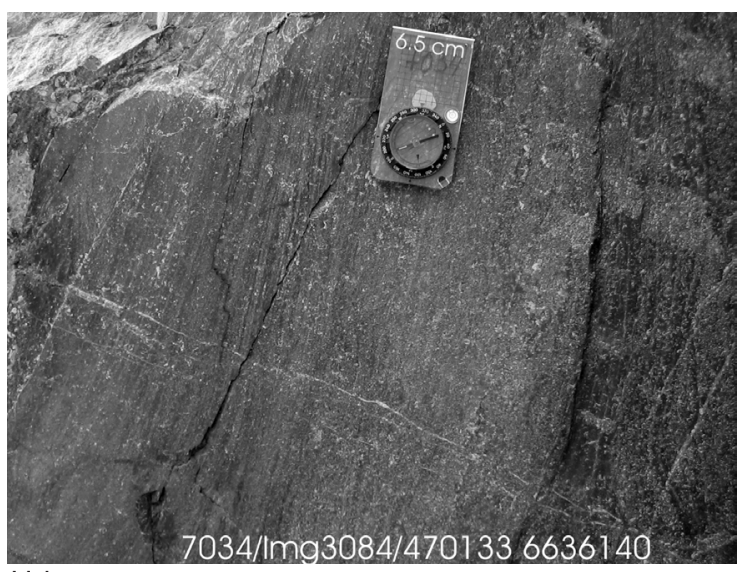

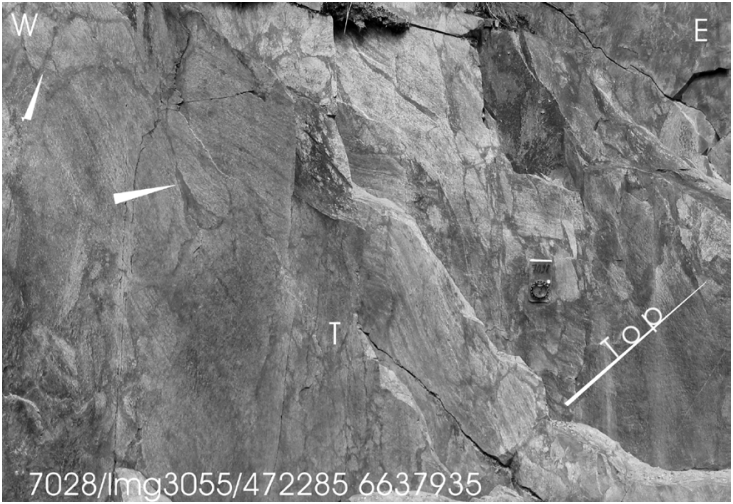

I le

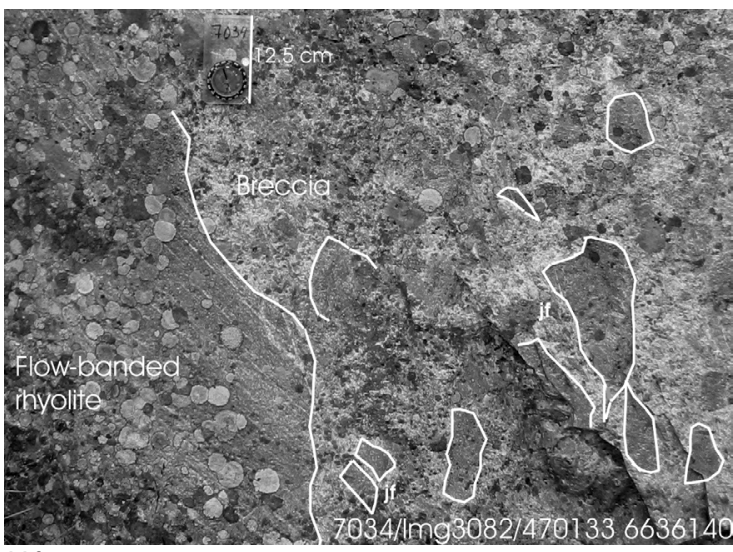

IIf

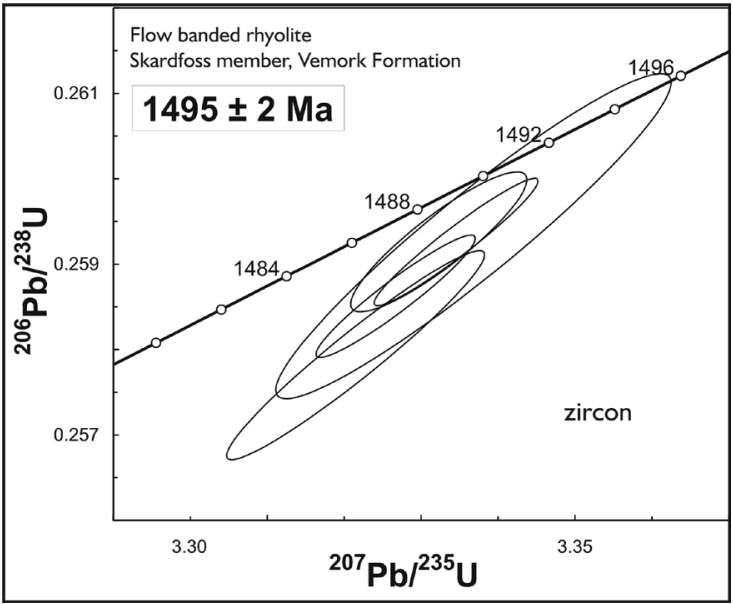

$\mathrm{IIg}$ 
(1973). Details of the current procedure are summarized in Corfu (2004). Zircon crystals extracted from the rhyolite are euhedral, short-prismatic, and exhibit mainly $\{100\}$ and $\{110\}$ crystal faces. Most crystals are pinkish and locally turbid and fractured. Analyses were carried out on 3 tips and 2 full prisms, mechanically abraded to remove the exterior of the grains and fractured domains. They yield five overlapping data points that are 1.2 to $0.5 \%$ discordant (Table 1; Fig. $11 \mathrm{~g})$. Lines projected through the data from lower intercept ages at 0 and $400 \mathrm{Ma}$ define upper intercept ages of 1494 to $1496 \mathrm{Ma}$. On this basis we conclude that an age of $1495 \pm 2$ Ma best reflects the extrusion of the rhyolite. The lithostratigraphic significance of this age was discussed in section 5.2.

\subsection{Sequence above the Skardfoss member}

The Skardfoss lava breccia is overlain by a thin tuffitic schist followed by a basaltic metalava, above which there is a typical Vemork sequence of alternating basaltic and sedimentary units (Fig. 11a). Sedimentary rocks are well-exposed in the valley of the Måne River between the Skardfoss dam and Vemork. They include volcaniclastic pebbly sandstones and tuffites and may be correlated with the S5 unit in the Frøystaul area. The major upper part of the section is, however, forest-covered.

\section{Lithostratigraphy of the Vemork formation in the Venutan area}

The Venutan area comprises the eastern margin of the Heidalsnutan dome, where the Tuddal formation is overlain by the Vemork formation in the east (Fig. 7). The contact between the formations is here also interbedded and the Vemork sequence is dominated by massive or amygdaloidal metabasalts with sedimentary interunits whose amount and thicknesses are, however, much smaller than in the Frøystaul-Vemork area. An exceptional feature is a felsic volcanite unit, named informally the Venutan member (could also be treated as a formation) in the upper part of the Vemork sequence (Fig. 12).

\section{I. Structure of the area}

The area is pervasively foliated and primary bedding can be observed only in metasedimentary units. The top and bedding determinations made in them indicate that the Vemork formation forms a steeply dipping, N-S trending, and east facing unit about 2 $\mathrm{km}$ thick (cf. Dons \& Jorde, 1978). The Raudsinutan fault separates it from the Vindeggen group in the east except in the Rindebekken area, where the upper contact is preserved (Section 9.2). The Brureskard fault cuts the Vemork formation in the north (Fig. 6).

Fig. I I. Lithologies of the Vemork formation in the Vemork area (a-f) and U-Pb concordia diagram of the Skardfoss sample (g). For locations of the road-cut outcrop along the R37 in figures b-f see Fig. 5. (a) Southern wall of Vestfjorddalen revealing the layered nature of the Vemork formation. Rjukan. (b) Epidotized volcanite boulder in pebbly matrix. Lower part of the Maristi member.Vemork. (c) Matrix-supported pebble conglomerate capped by parallel-laminated sandstone (Sp) with solitary pebbles (arrow). Upper part of the Maristi member.Vemork. (d) Dated flow-banded metarhyolite of the Skardfoss member. $1.5 \mathrm{~km} \mathrm{SW}$ of Vemork. (e) Autobreccia at the upper contact of the flow-banded metarhyolite of the Skardfoss member. Note the jigsaw fit breccia on the left (arrows) cut by tectonic foliation ( $T$ ) and passing upwards to a slightly reworked breccia.Vemork. (f) Hyaloclastic breccia at the upper contact of the flow-banded metarhyolite of the Skardfoss member. Gray patches are lichen. The upper contact of the coherent lava and margins of some of the clasts are outlined. Note the curviplanar nature of the contact and margins of the clasts, and jigsaw-fit relation of a couple of the clasts (jf). $1.5 \mathrm{~km} \mathrm{SW}$ of Vemork. (g) Concordia diagram presenting ID-TIMS U-Pb data on zircon from the Skardfoss flow-banded rhyolite. 


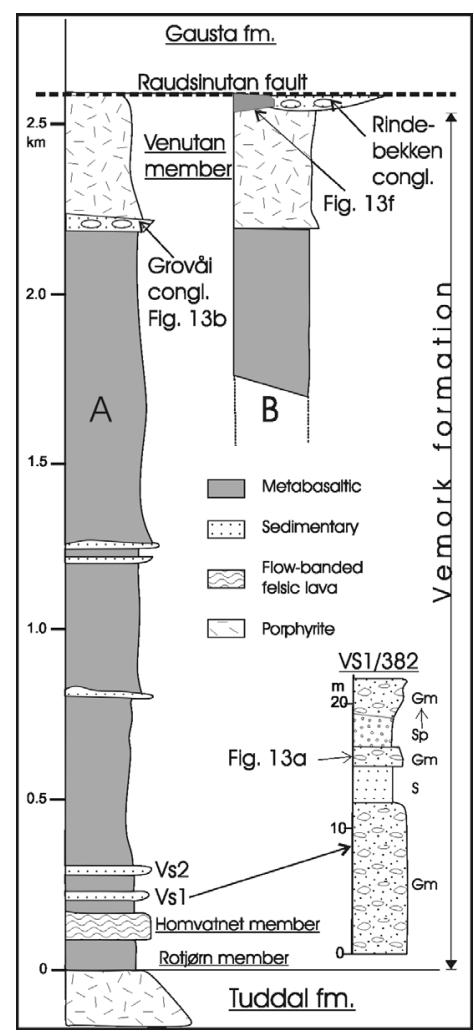

Fig. 12. Lithostratigraphic columns of the Homvatnet (A) and Rindebekken areas (B). For locations see Fig. 7. Lithofacies codes for unit VSI: Gm $=$ matrix supported conglomerate, $S$ $=$ sandstone, $\mathrm{Sp}=$ pebbly sandstone. Stratigraphic positions of Figs. I 3a, b \& $f$ are shown.

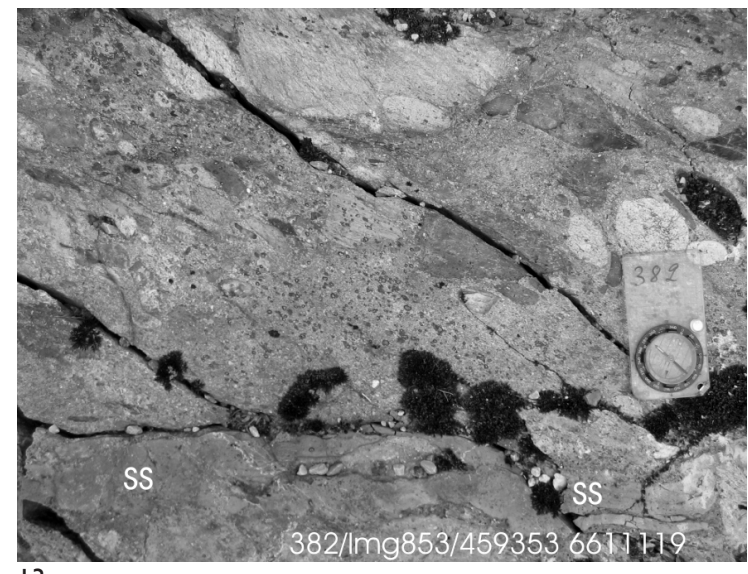

$13 a$

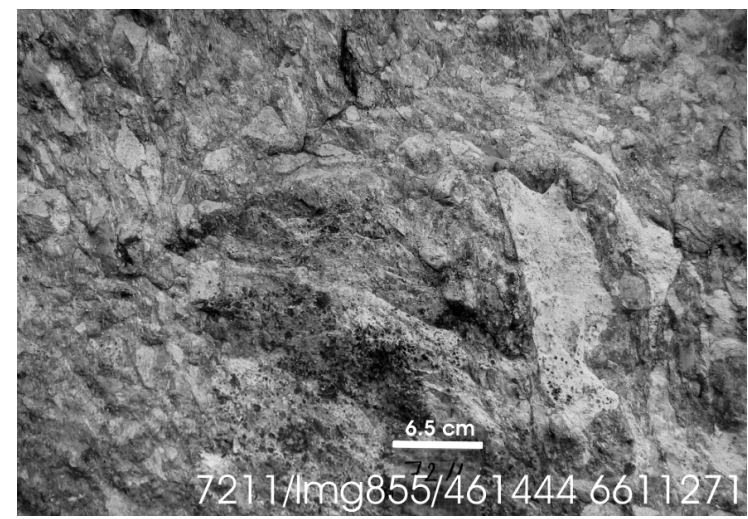

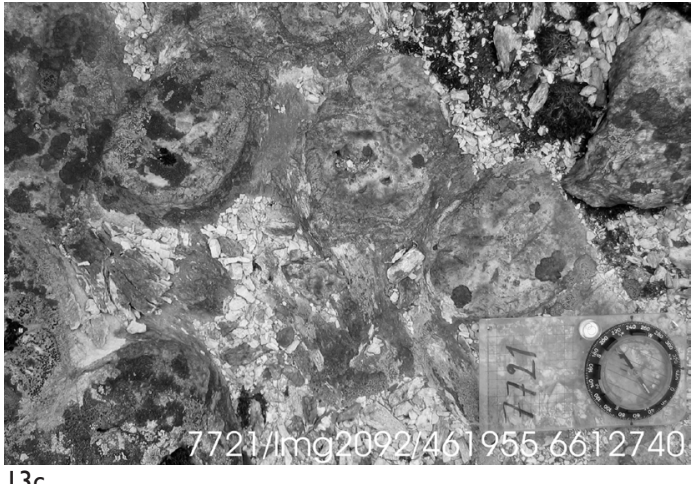

$13 c$

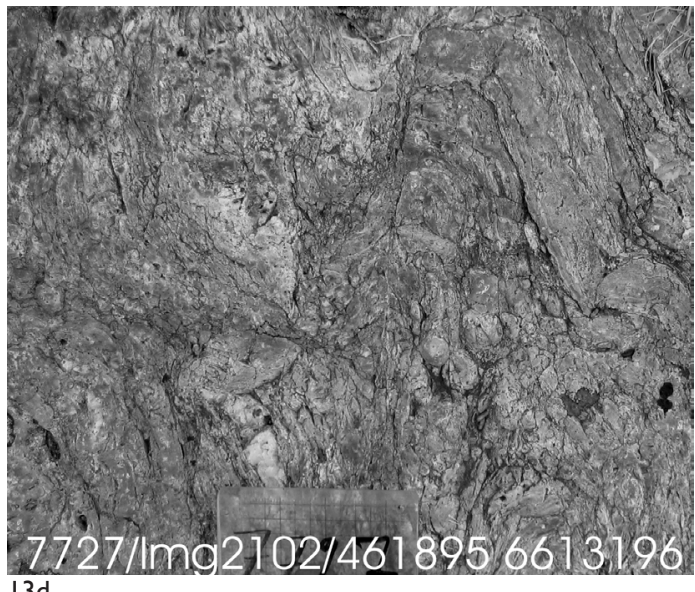

$13 \mathrm{~d}$

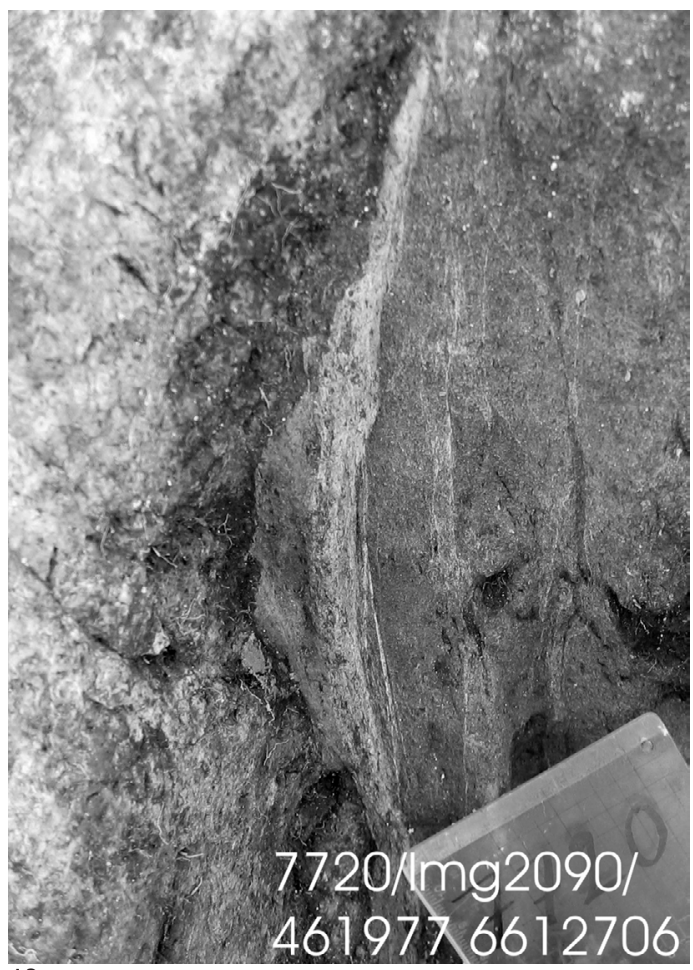

$13 \mathrm{e}$ 


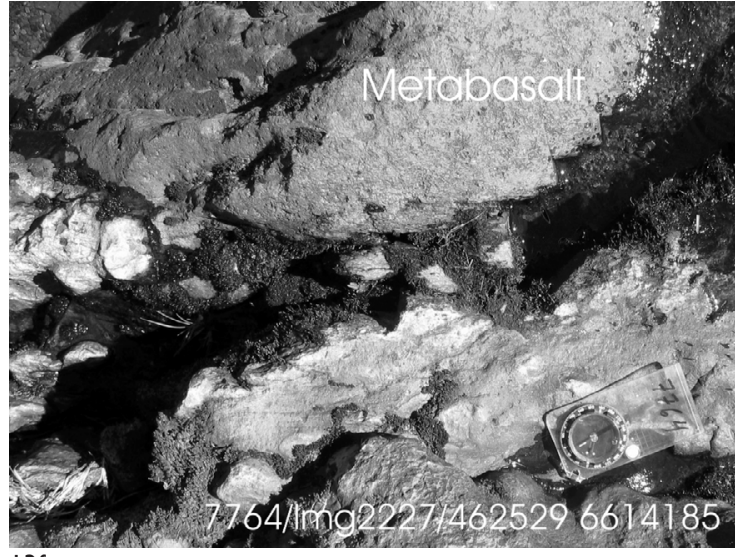

I3f

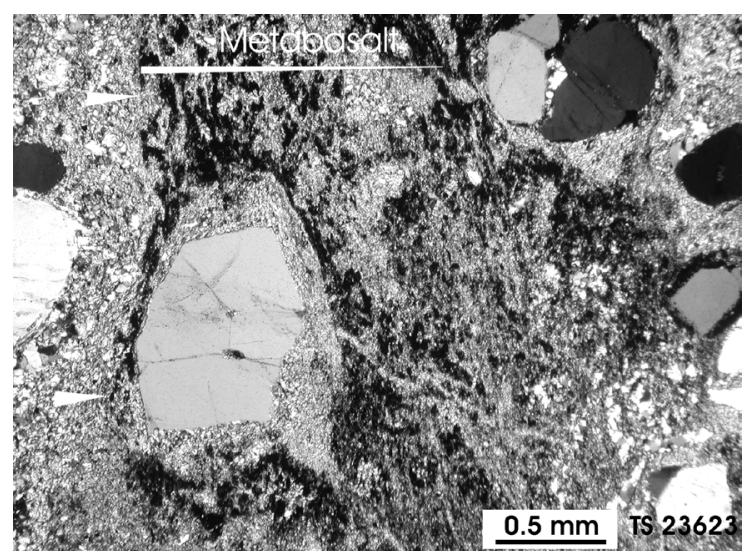

I3g

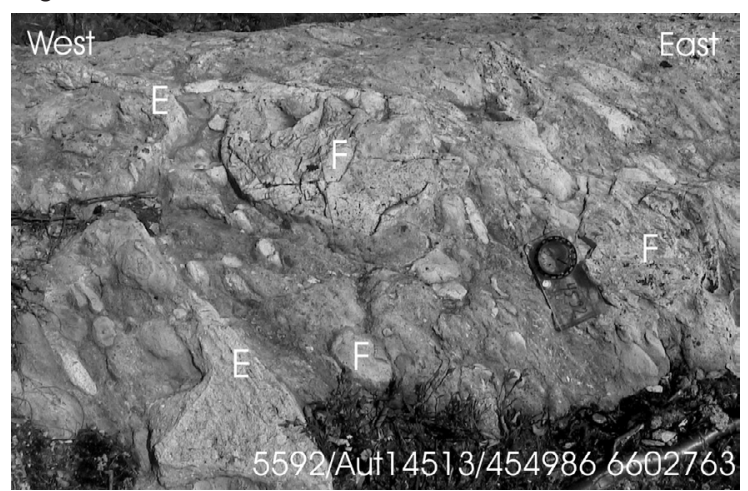

$13 \mathrm{~h}$

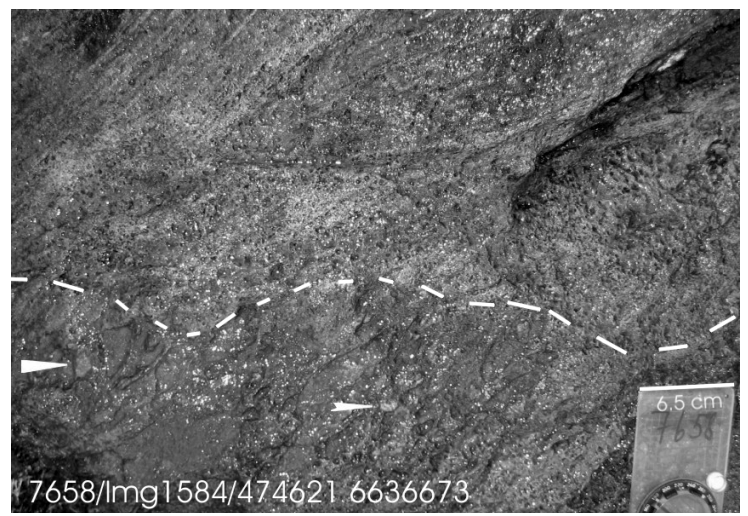

$13 \mathrm{i}$

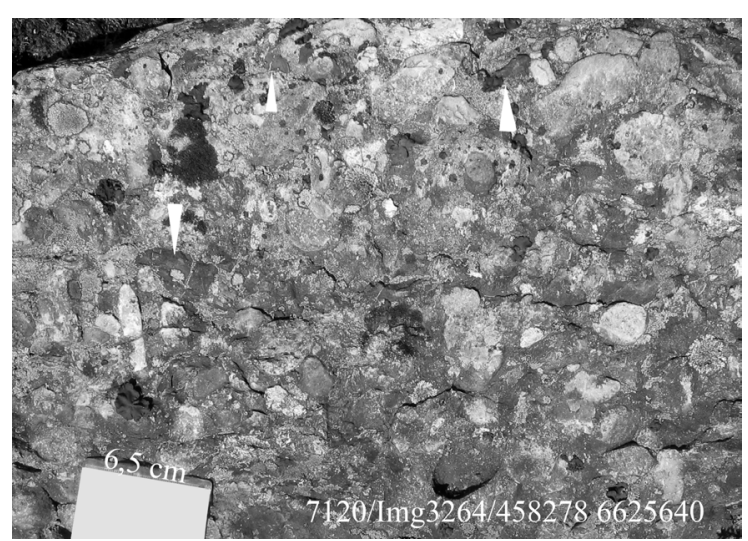

$13 \mathrm{j}$

Fig. 13. Lithologies of the Vemork formation in the Venu$\tan (\mathrm{a}-\mathrm{g})$, Trovasshovet (h), and Diplanuten (i) areas and a conglomerate in the Gausta formation (j). For locations see Figs. 7, 2, 5, and 6, respectively. a) Pervasively foliated, matrix-supported polymictic cobble conglomerate of the Vemork unit VSI north of Homvatnet with both felsic and mafic clasts. SS = thin sandstone interbed. b) Grovåi conglomerate with angular-subangular, predominantly felsic volcanite clasts. South of the Grovåi River. c) Lithophysae lava. d) Tectonically folded flow-banded felsic lava with solitary lithophysae from the Venutan member outlier in Fig. 7. e) Erosional western (lower) contact of the Venutan member. $f$ ) Eastern (upper) contact of the lithophysae (white roundish domains) lava of the Venutan member with the overlying metabasalt. A river bed outcrop. Rindebekken. g) Microphotograph of the contact (arrows) in Fig. I 3f. Quartz phenocrysts derived from the felsic lava lie in a sericite-opaque mass representing the altered basalt. The sericite-rich rim around the largest phenocryst is interpreted as altered groundmass of the felsic lava. Two polars. h) Matrix-supported conglomerate with large boulders of felsic volcanite (F), diverse smaller mafic volcanite clasts, and epidote (E) veins and patches. Trovasshovet. i) Erosional contact (dashed line) between a trough cross-bedded biotitic sandstone and a weathered Vemork metabasalt (lower margin of the figure) with solitary felsic patches (arrows). Diplanuten. Tiny pits reflect dissolved carbonate porphyroblasts. j) Polymictic Bossnuten-type conglomerate with well-rounded hematite-coated quartzite pebbles with less abundant, distinctive red jaspis (arrows) and minor felsic volcanite clasts. Bossnuten. 


\subsection{Rotjørn member}

The lowermost, about c. 150 m wide metabasalt unit rimming the main Tuddal body of the Heidalsnutan dome is named the Rotjørn member (Figs. 7, 12). On a previous map (Dons, 2003), part of the member was marked as metadiabase, but abundant amygdules indicate a subaerial origin for the rock. Both the lower and upper contacts of the member are unexposed.

\subsection{Homvatnet member}

The 100-150 m wide felsic volcanite unit between the Rotjørn member and the main Vemork formation north of Homvatnet is named informally the Homvatnet member (Figs. $7 \& 12$ ). The bulk of the member is made up of a flow banded rhyolite similar to that of the Skardfoss member except that it locally contains lithophysae-like structures. Both the lower and upper contacts of the member are unexposed. The member is overlain either by a basalt or a polymictic conglomerate with both felsic and basic volcanic clasts.

\subsection{The Vemork formation between the Homvatnet and Venutan members}

The main part of the formation consists of massive or amygdaloidal basalts. In the lower part, however, two thicker conglomeratic units occur (VS1 and VS2 in Fig. 12). The conglomerates resemble the Maristi conglomerate being matrix-supported and containing both mafic and felsic volcanite clasts in a mafic matrix (Fig. 13a). The more than $20 \mathrm{~m}$ thick unit VS1 comprises matrix-supported conglomerate beds separated by thinner sandstone beds (detailed column in Fig. 12). Only a few, thin sandstone units occur higher in the stratigraphy. Like in the Frøystaul area, clast size in the sedimentary beds decreases upwards.

West and south of Homvatnet, the Vemork formation narrows significantly and dies out due to the deep erosion caused by the formation of the sub-Eidsborg unconformity. Long road cuts c. $3 \mathrm{~km}$ south of Homvatnet show that the preserved $600 \mathrm{~m}$ thick sequence consists almost solely of basalts with thin beds of volcaniclastic conglomerates in basal and upper parts.

\subsection{Grovåi conglomerate}

A volcaniclastic conglomerate occurs in small outcrops on a steep mountain flank between a Vemork basalt and the Venutan member south of the Grovåi River (lower inset in Fig. 7). The conglomerate is matrix supported and poorly sorted with angular pebblecobble size fragments mainly of felsic, but also of mafic volcanic rocks in sericite-rich matrix with carbonate porphyroblasts (Fig. 13b). The rock is so strongly foliated that no primary structures are visible making it hard to tell whether it represents a pyroclastic or a volcanogenic sedimentary deposit. Its contacts are not exposed, but as the Vemork formation faces consistently to the east, it was most likely deposited on the Vemork metabasalt only c. $20 \mathrm{~cm}$ apart.

\subsection{Venutan member}

Dons (2003) included the $10 \mathrm{~km}$ long and $0.5-1 \mathrm{~km}$ wide porphyry body between the Vemork metabasalts and the Gausta formation, east of the Heidalsnutan dome, into the Tuddal formation. The porphyry is considered in this study as a separate unit named informally the Venutan member (Fig. 7). Only its narrow southern part and a partial section along the Rindebekken River (upper inset in Fig. 7) were studied by the present author. The lithology of the member varies. The southwesternmost rock exposed east of the Grovai conglomerate is a porphyry containing quartz and feldspar phenocrysts in a felsic, in part spherulitic groundmass. In the central part of the member, lithophysae lavas (Fig. 13c), flow-banded lavas with minor lithophysae (Fig. 13d) and felsic volcanic breccias and conglomerates occur. All the rocks are pervasively foliated and thin sandstone interbeds indicate that the unit is folded tightly.

Because no top determinations are available in the Venutan area and due to metamorphism and deformation of the rocks, the relationship of the Venutan member with the surrounding Vemork basalts is hard 
to be established. This problem was tried to be solved by studying both the western and eastern contacts of the Venutan member. Three different varieties of the western contact were detected: (1) a thin, dark biotiterich seam at the outer margin of the basalt against the Venutan porphyry, which may represent a thermometamorphic contact of the basalt "baked" by the porphyry. (2) The porphyry seems to erode the thinly banded rock lying between it and the basalt (Fig. 13e). (3) Biotite rich-fragments (c. $0.5-1 \mathrm{~mm}$ long) with diffuse margins and felsic domains surrounded by biotite abound at the contact zone indicating mingling of the felsic lava with the basaltic one. Furthermore, the Venutan member onlaps topographically and lies as small outliers on the Vemork metabasalts (Fig. 7), and the Grovåi conglomerate seems to floor a palaeovalley (lower inset in Fig. 7). All these observations indicate that the felsic Venutan lava was extruded upon the Vemork basalts lying west of it.

The eastern contact of the Venutan member is exposed in the Rindebekken River, where a lithophysae rock is in direct contact with a basalt (upper inset in Fig. 7). The contact is erosional with a palaeorelief of several tens of centimetres carved into the felsic lava (Fig. 13f). As it is logical to suppose that the abundance of lithophysae indicate the upper part of the felsic lava, the basalt most probably extrude upon the Venutan member at this locality. It seems also to have been mingled with the felsic lava as abundant quartz-phenocrysts and sericitized domains (likely altered feldspar phenocrysts) occur in a opaque- and sericite-rich rock (likely altered basaltic material) at the felsic lava/basalt contact (Fig. 13g, cf. Fig. 9b in Laajoki, 2006). Consequently, being most likely both underlain and overlain by Vemork basalts, the Venutan member either interfingers or is interbedded with the basalts of the uppermost part of the Vemork formation. The features suggesting lava mingling indicate that the felsic Venutan magmatism was coeval with the closing stage of the basaltic Vemork magmatism.

\section{Western and southern margin of the Heidalsnutan dome}

The western margin of the Heidalsnutan dome is marked by a discontinuous belt of basaltic rocks, some of which have been included into the Vemork formation and some have been considered younger (Dons, 2003). Intense shearing, however, makes their correlation difficult. At Trovasshovet, several Maristi-type conglomerate beds with boulders of both felsic and mafic volcanites (Fig. 13h) are interbedded with metabasalts. Dons (op. cit) included them into the Røynstaul formation, but Laajoki and Lamminen (2006, their Fig. 6) showed that they, as well as the small basalt occurrences rimming the southern tip of the Heidalsnutan dome SE of Trovasshovet, belong to the Vemork formation.

Basalts occur also north of Trovasshovet along the western margin of the Heidalsnutan dome (Dons, 2003), but their ages are unknown. If the Vemork formation was ever present there in any significant thickness on top of the Tuddal formation most of it must have been eroded or transported tectonically away, since the Tuddal formation is now covered either by the Oftefjell or Høydalsmo group or has tectonic contacts with them (op.cit.).

\section{The upper contact of the Vemork formation}

In its main distribution area from Vemork to Bossnuten, the Vindeggen group overlies the Vemork formation. The Venutan member east of Venutan is overlain by the Rindebekken conglomerate or has a fault contact with the Vindeggen group, whereas SE of Venutan the Eidsborg formation overlies the Vemork sequence.

\section{I.Vemork formation/Vindeggen group contact}

The Vemork formation/Vindeggen group contact corresponds to Dons' (1960a, b) Rjukan group/Seljord group contact. Its nature has been disputed. Weren- 
skiold, (1910, p 11) considered it as a likely discordance, Wyckoff (1934, p. 15) as a large unconformity, and Dons (1960a, p. 50; 1960b, p. 6) as an angular unconformity. Dahlgren et al. (1990) considered the contact as conformable. Brewer and Menuge (1998) stated that the Rjukan and Seljord (Vindeggen group in present usage) groups represent one package within which the discordance of individual units is a function of the mode of deposition, whereas Sigmond (1998) was of the opinion that the Seljord group lies discordantly on the Rjukan group. Falkum and Petersen (1980, p. 630) suggested that the major angular unconformity proposed by Wyckoff and Dons could be interpreted as the result of fault tectonics following the deposition of the individual series. Richards (1995) concluded that the Rjukan group was deformed before the deposition of the Seljord group.

The main problem is that the contact between the Vemork and Gausta formations is mostly either unexposed or intensely sheared (Figs. $3 \& 8 b$, d). The only locality where it seems to have been preserved is north of Diplanuten (Fig. 5), where the uppermost Vemork amygdaloidal rock is in primary contact with a cross-bedded sandstone (Fig. 13i). The sandstone is a quartz-feldspar wacke with biotite-chlorite-rich matrix. It becomes cleaner upwards passing via crossbedded arkosites into a typical glassy Gausta quartzite. A similar gradual change can be seen also along the Grasfjell shear zone in the Litle Langvasstødalen (Figs. $5 \& 8$ b), where the Gausta quartzite is underlain by a sheared sandstone with felsic volcanite pebbles and granules, and north of Bossnuten (Fig. 6), where the rocks of the contact zone are pervasively deformed by Richards' $S_{3}$ foliation (Fig. 8d). In both the cases, bedding in the Vemork formation seems to follow that of the Gausta formation. The latter contains polymictic conglomerate beds with well rounded orthoquartzite pebbles and minor felsic volcanite and red jaspis clasts in its lowermost part. These conglomerates are called the Bossnuten type (Fig. 13j). These observations support Dahlgren et al's (1990a) interpretation of a conformable contact between the Vemork formation and the Seljord (Vindeggen) group.

\subsection{Venutan member/Rindebekken conglomerate contact (sub-Rindebekken unconformity)}

The contact between the Venutan member and the Rindebekken conglomerate (Figs. $7 \& 12 \mathrm{~b}$ ) is not exposed, but the volcaniclastic Rindebekken conglomerate containing solely porphyry clasts in a felsic volcanic detritus occurs immediately east of the Venutan porphyry. It is followed by alternating arkosite and felsic volcaniclastic conglomerate beds overlain by the east-facing Gausta quartzite. The felsic conglomerate indicates a significant erosional period after the Venutan porphyry was formed. However, in Venutan and south of it, the Venutan member and the Gausta formation are in tectonic contact being separated by the Raudsinutan fault. Consequently, it is quite possible that the western contact of the Gausta formation is tectonic also in the Rindebekken area. In this case, the Rindebekken conglomerate could represent an intra-Vemork weathering period.

\subsection{Vemork formation/Eidsborg formation contact}

The upper contact of the Vemork formation rimming the SW margin of the Heidalsnutan dome is marked by the angular sub-Eidsborg unconformity (Fig. 7). Note that this unconformity was previously correlated with the sub-Røynstaul unconformity (Laajoki \& Lamminen, 2006), but recent U-Pb datings of detrital zircons indicate that the overlying formation may be correlated with the Eidsborg formation (Lamminen, written comm., 2006).

\section{Discussion}

The lithostratigraphy of the Vemork formation treated in this paper is bipartite consisting mainly of basaltic lavas with subordinate sedimentary interunits, which lie between the c. 1.5 Ga Tuddal formation and the Vindeggen group over $1.15 \mathrm{Ga}$ old. The main problem is, however, the nature of the lower and upper contacts of the Vemork formation. The lower contact is related to the transition from conti- 
nental felsic volcanism to dominantly basaltic volcanism, whereas the upper contact reflects cessation of the volcanism and beginning of an extensive fluvialmarine sedimentation.

The abrupt switch from felsic to basaltic volcanism and the deposition of the Maristi-type conglomerates, indicate that, although no great unconformity can be seen between the Tuddal and the Vemork formations, they represent two different evolutionary stages of the Rjukan rift. The large epidotized boulders in the Maristi conglomerate (Fig.11b) are important in this respect. Their size (up to $1.5 \mathrm{~m}$ ) indicate that they were most likely derived from a nearby source, probably either from the Vårskarven or Dalsnuten dome or from their pre-Maristi cover. Brewer \& Atkin (1987) attributed the filling of vesicles in and epidotization of the metabasalts to burial metamorphism. This suggests that part of the Vemork basement went trough subsidence and uplifting before the deposition of the Maristi conglomerate. Consequently, the possibility of an angular unconformity between the Tuddal and Vemork formations can not be completely excluded (cf. Laajoki, 2005). Another alternative is that the epidotization was due to syndepositional hydrothermal alteration implying only significant erosion of the pre-Maristi basalts.

The relation between the lower contact of the Vemork formation and the sub-Heddersvatnet unconformity in the Heddersvatnet area (Figs. 2 \& 14), about $10 \mathrm{~km}$ east of Diplanuten (Fig. 5) remains an open question. As the Vemork formation is missing there, the Heddersvatnet formation, the basal unit of the Vindeggen group, lies directly on the Tuddal formation. A minor metabasalt occurs, however, higher in the stratigraphy within the Heddersvatnet formation (Andersen \& Laajoki, 2003). Already Wyckoff (1934) considered their contact, e.g. the sub-Heddersvatnet unconformity, as a great angular unconformity. This possibility is still compatible with recent studies (Laajoki, 2005). The Heddersvatnet formation contains in its basal conglomerates orthoquartzite pebbles, which in the Diplanuten area first appear in the basal parts of the Gausta formation indicating that these lithostratigraphic levels could be correlat-

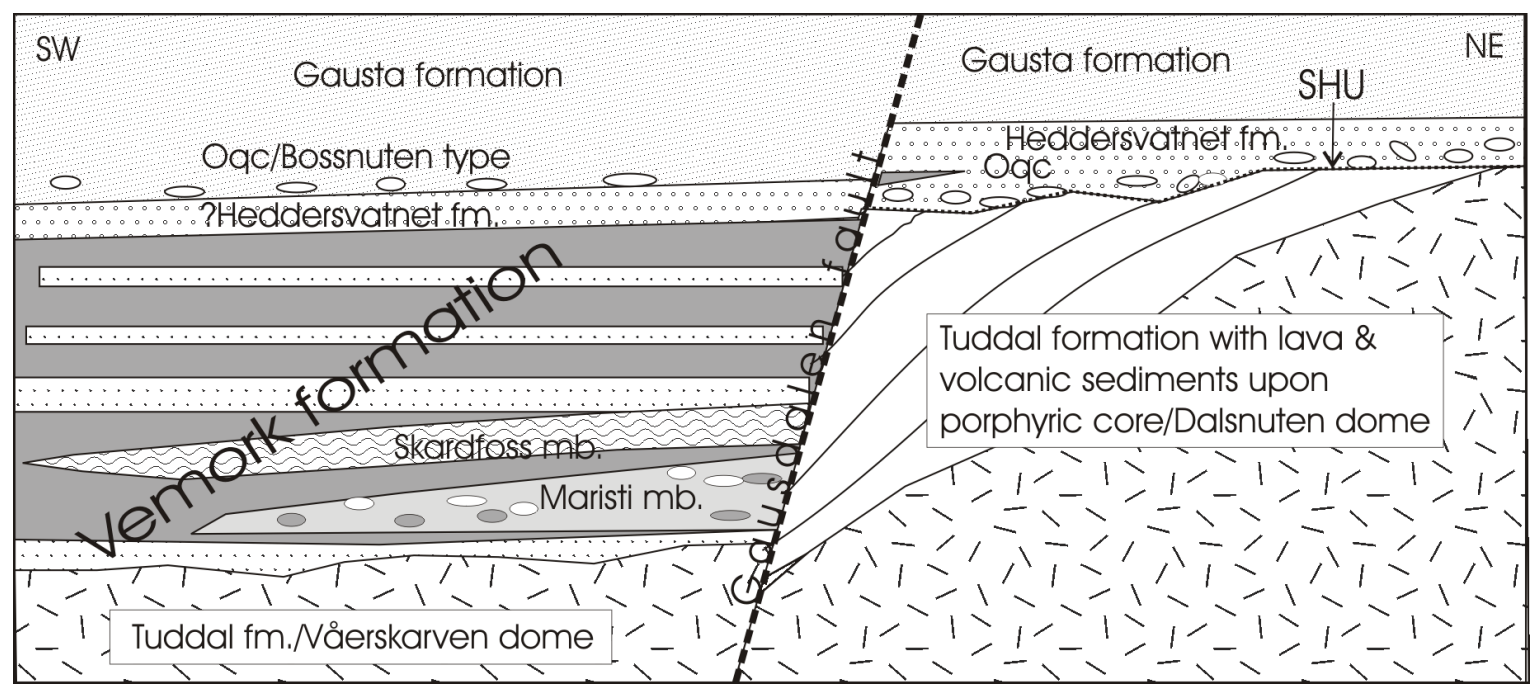

Fig. I4. Schematic correlation of the formations across the Gausdalen fault. Oqc = conglomerate with orthoquartzite clasts (Bossnuten type SW of the fault). Note that the age of the inferred Gausdalen fault is unknown. Thicknesses of the sedimentary units (stippled) in the Vemork formation are exaggerated. SHU = sub-Heddersvatnet unconformity. 

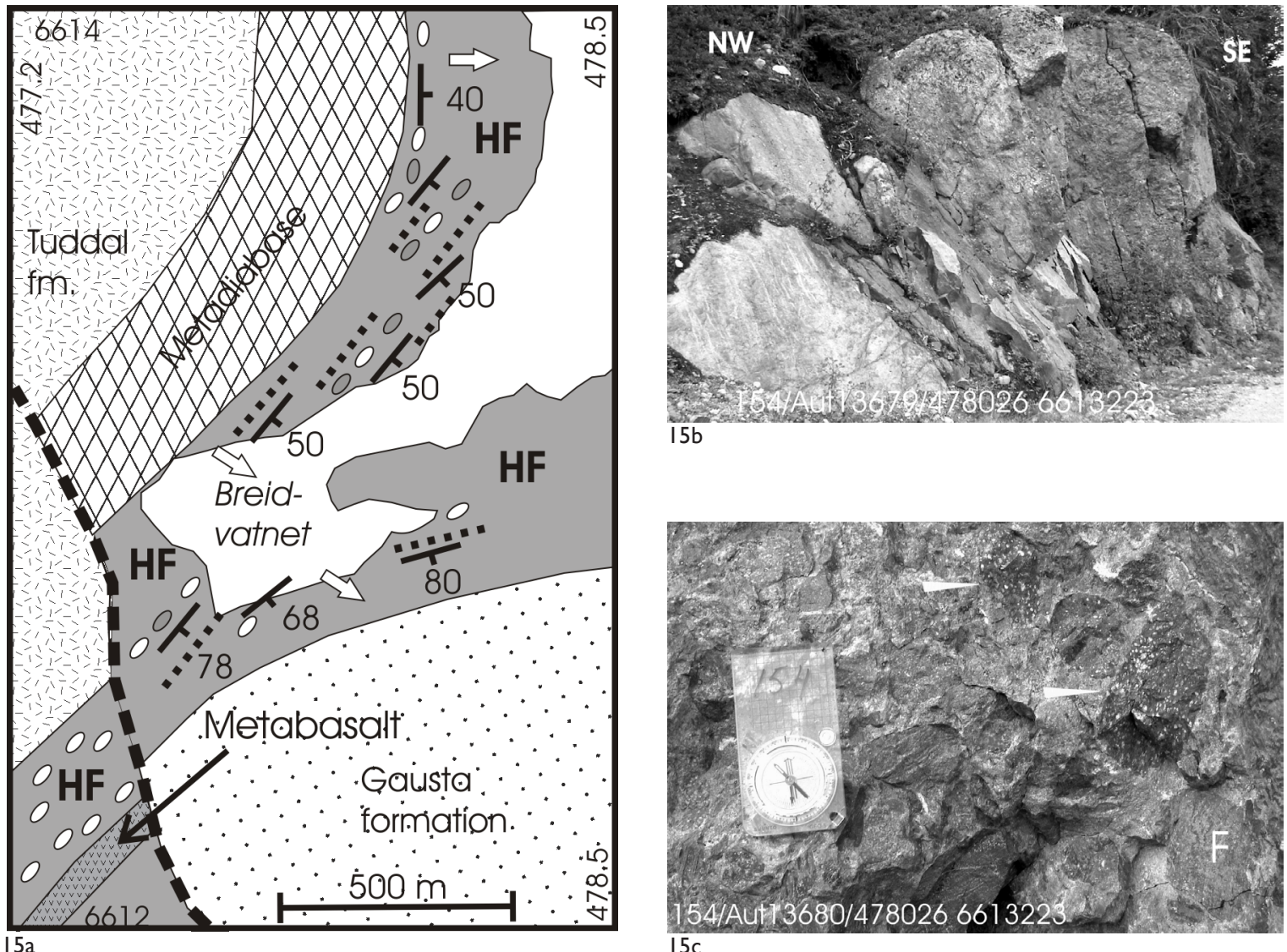

Fig 15. a) Geological map of the Breidvatnet area (for location see Fig. 2). HF = Heddersvatnet formation (gray). Alternating polymictic volcaniclastic conglomerate and arkosite beds are shown by ellipsoids and point rows, respectively. Note the metabasalt in the left lower corner. Arrows and the broken line indicate top direction and a fault, respectively. b) C. I.5 m thick polymictic volcaniclastic conglomerate lying on volcaniclastic sandstone of the Heddersvatnet formation. c) Close up of the volcaniclastic conglomerate with two amygdaloidal metabasalt (arrows) and porphyric or flow-banded (F) felsic volcanite clasts.

ed (Fig. 14). It is possible that the Heddersvatnet and Vemork formation are interfingering and that their lower contacts could represent the same unconformity (legend in Fig. 2 \& op. cit.), but the time gap it represents would be much greater under the Heddersvatnet formation than under the Vemork formation. Laajoki (2005) suggested that the Heddersvatnet area could represent a highland or rift shoulder, which was exposed to erosion for a longer time than the area occupied by the Vemork formation. Because the Diplanuten and Heddersvatnet areas are separated by the
Gausdalen fault and the Gaustatoppen Mountain, this correlation must be left open until more structural and lithostratigraphic data from their basement become available. The correlation is, however, supported by the Breidvatnet area, c. $20 \mathrm{~km}$ south of Heddersvatnet, where the Vemork formation is missing, but the basal Heddersvatnet formation contains alternating beds of volcaniclastic sandstones and conglomerates with one metabasalt interunit (Figs. 15a, b). The conglomerate contains metabasalt clasts (Fig. 15c) similar to those in the Vemork conglomerates 


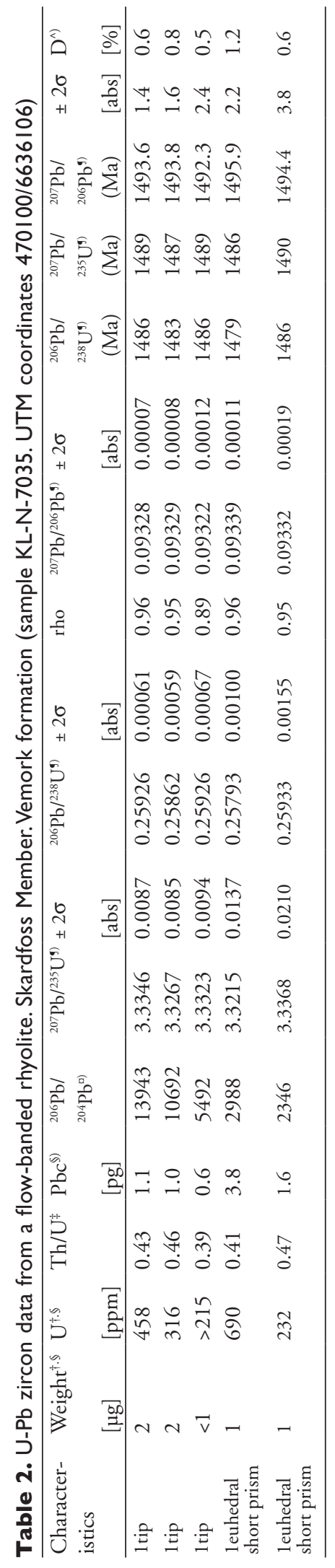

indicating that metabasalts or conglomerates containing their clasts were exposed for erosion during the deposition of the Heddersvatnet formation.

The Vemork formation has not been described under this name outside the area in Fig. 2, but farther to the north small occurrences of conglomerates with greenstone matrix and metabasalts lie on the Tuddal formation (Sigmond, 1998). Bingen et al. (2005) considered the $<1508 \pm 8$ Ma Gøyst metasupracrustals complex, c. $30 \mathrm{~km}$ north of Rjukan, as a possible correlative of the Heddersvatnet formation, but, as it also contains volcanic rocks (Sigmond, 1998), it could alternatively be correlated with the Vemork formation or their interbedded combination. The structure and metamorphism of the complex, however, differ so much from those in the Vemork formation that such a correlation is speculative.

The present study seems to support the idea that the Tuddal and Vemork formations and the Vindeggen group represent one package within which the discordance of individual unit is a function of the mode of deposition (Brewer \& Menuge, 1998). They represent, however, three quite contrasting units indicating that the Tuddal/Vemork and Vemork/Vindeggen boundaries reflect important tectonic changes in the volcanic-sedimentary evolution of the Rjukan rift basin (cf. Sigmond et al., 1997). Regional tectonic synthesis is, however, necessary before the nature and causes of these changes can be understood properly.

\section{Conclusions}

The Vemork formation is a c. $2 \mathrm{~km}$ thick sequence of greenschist facies subaerial metabasalts-greenstones with intervening volcaniclastic mass flow and fluvial sedimentary units. It is underlain and overlain seemingly conformably by the $1.5 \mathrm{Ga}$ continental felsic volcanites of the Tuddal formation and the fluvialshallow marine Vindeggen group, respectively. The $1495 \pm 2$ Ma old Skardfoss member near the lower contact gives the approximate lower age limit for the formation. 


\section{Acknowledgements}

The authors would like to thank first Johan Dons for several discussions and for his and co-authors' excellent maps without which this and authors' other Telemark studies would never had been published. This study is part of the joint research between the Department of Geology of the University of Oulu and the University of Oslo. The Academy of Finland (projects $207099 \& 207346)$, the Research Council of Norway (project 154219/432), and the Geological Survey of Norway (project No. 265900) have provided financial support. The useful reviews by B. Bingen and K. Saalmann are gratefully acknowledged.

\section{References}

Andersen, T., 2005. Terrane analysis, regional nomenclature and crustal evolution in the Southwest Scandinavian Domain of the Fennoscandian Shield. GFF 127, 159-168.

Andersen, T. \& Laajoki, K., 2003. Provenance characteristics of Mesoproterozoic metasediments from Telemark, South Norway. A Nd-isotope mass balance model. Precambrian Research 126, 95-122.

Bingen, B., Birkeland, A., Nordgulen, Ø. \& Sigmond, E.M.O., 2001. Correlation of supracrustal sequences and origin of terranes in the Sveconorwegian orogen of SW Scandinavia: SIMS data on zircon in clastic metasediments. Precambrian Research 108, 293-318.

Bingen, B., Nordgulen, Ø., Sigmond, E.M.O., Tucker, R., Mansfeld, J. \& Högdahl, K., 2003. Relations between 1.19 - $1.13 \mathrm{Ga}$ continental magmatism, sedimentation and metamorphism, Sveconorwegian province, $S$ Norway. Precambrian Research 124, 215-241.

Bingen, B., Skår, Ø., Marker, M., Sigmond, E. M.O., Nordgulen, Ø., Ragnhildstveit, J., Mansfeld, J., Tucker, R. D. \& Liégeois, J.-P., 2005. Timing of continental building in the Sveconorwegian orogen, SW Scandinavia. Norwegian Journal of Geology 85, 87-116.

Brewer, T.S., 1985. Geochemistry, geochronology and tectonic setting of the Proterozoic Telemark supracrustals, Southern Norway. PhD Thesis, University of Nottingham, 380 p.

Brewer, T.S. \& Atkin, B.P., 1987. Geochemical and tectonic evolution of the Proterozoic Telemark supracrustals, southern Norway. Geological Society Special Publication 33, 471-487.

Brewer, T.S. \& Atkin, B.P., 1989. Elemental mobilities produced by low-grade metamorphic events; a case study from the Proterozoic supracrustals of southern Norway. Precambrian Research 45, 143-158.
Brewer, T.S. \& Field, D., 1985. Tectonic environment and age relationships of the Telemark supracrustals. NATO ASI Series, Series C: Mathematical and Physical Sciences 158, 291-307.

Brewer, T.S. \& Menuge, J.F., 1998. Metamorphic overprinting of Sm-Nd isotopic systems in volcanic rocks. The Telemark Supergroup, southern Norway. Chemical Geology 45, 1-16.

Corfu, F., 2004. U-Pb age, setting, and tectonic significance of the anorthosite-mangerite-charnockite-granitesuite, Lofoten-Vesterålen, Norway. Journal of Petrology 45, 1799-1819.

Dahlgren, S.H., Heaman, L. \& Krogh, T.E., 1990. Geological evolution and U-Pb geochronology of the Proterozoic central Telemark area, Norway (abstract). Geonytt 17 , p. 38.

Dons, J.A., 1960a. Telemark supracrustals and associated rocks. In: Holtedahl, O. (ed.) Geology of Norway. Norges geologiske undersøkelse 208, 49-58.

Dons, J.A., 1960b. The stratigraphy of supracrustal rocks, granitization and tectonics in the Precambrian Telemark area. Southern Norway. Norges geologiske undersøkelse $212 \mathrm{~h}, 1-30$.

Dons, J.A., 1961. Berggrunnskart. Rjukan; 1:100 000. Norges geologiske undersøkelse. Trondheim.

Dons, J.A., 2003. Berggrunnskart ÅMOTSDAL 1514 II, M 1:50 000. Norges geologiske undersøkelse.

Dons, J. \& Jorde, K., 1978. Geologisk kart over Norge, berggrunnskart Skien; 1:250 000. Norges geologiske undersøkelse.

Dons, J.A., Heim, M. \& Sigmond, E.M.O., 2004. Berggrunnskart FRÖYSTAUL 1514 I, M 1:50 000. Norges geologiske undersøkelse.

Falkum, T. \& Petersen, J.S., 1980. The Sveconorwegian orogenic belt, a case of late-Proterozoic plate-collision. Geologische Rundschau 69, 622-647.

Fischer, R.V., 1961. Proposed classification of volcaniclastic sediments and rocks. Bulletin of the Geological Society of America 72, 1409-1414.

Gaál, G. \& Gorbatschev, R., 1987. An outline of the Precambrian evolution of the Baltic Shield. Precambrian Research 35, 15-52.

Howard, J. L., 2005. The quartzite problem revisited. The Journal of Geology 113, 707-713.

Krogh, T.E., 1973. A low contamination method for hydrothermal decomposition of zircon and extraction of $U$ and $\mathrm{Pb}$ for isotopic age determinations. Geochimica et Cosmochimica Acta 37, 485-494.

Laajoki, K., 2005. The Mesoproterozoic sub-Heddersvatnet unconformity, Telemark, South Norway. Bulletin of the Geological Society of Finland 77, 49-63.

Laajoki, K., 2006a. The Mesoproterozoic sub-Lifjell unconformity, central Telemark, Norway. Bulletin of the Geological Society of Finland 78, 41-70.

Laajoki, K., 2006b. Lithostratigraphy of the lower part of the Mesoproterozoic Lifjell group, central Telemark, 
Norway. Res Terrae, Ser. A, No. 23, 47 p.

Laajoki, K., 2006c. Lithostratigraphy of the Mesoproterozoic Oftefjell group, central Telemark, Norway. Res Terrae, Ser. A, No. 24, 36 p.

Laajoki, K., 2007. The Mesoproterozoic sub-Svinsaga unconformity, central Telemark, Norway. Norwegian Journal of Geology, in press.

Laajoki, K. \& Lamminen, J. T., 2006. The Mesoproterozoic sub-Røynstaul unconformity, central Telemark, Norway. Norwegian Journal of Geology 86, 29-40.

Laajoki, K., Corfu, F. \& Andersen, T., 2002. Lithostratigraphy and $\mathrm{U}-\mathrm{Pb}$ geochronology of the Telemark supracrustals in the Bandak-Sauland area, Telemark, South Norway. Norsk Geologisk Tidsskrift 82, 119-138.

McPhie, J., Doyle, M. \& Allen, R., 1993. Volcanic Textures. Center for ore deposit and exploration studies, University of Tasmania, $196 \mathrm{p}$.

Menuge, J.F. \& Brewer, T.S., 1996. Mesoproterozoic anorogenic magmatism in southern Norway. In: Brewer, T.S. (ed.) Precambrian Crustal Evolution in the North Atlantic Regions. Geological Society Special Publication 112, 275-295.

Neumann, H. \& Dons. J.A., 1961. Geologisk kart. KVITESEID. M 1:100 000. Norges geologiske undersøkelse.

Nystuen, J.P., (ed.) 1986. Regler og råd for navnsetting av geologiske enheter i Norge. Av Norsk stratigrafisk komité. Norsk Geologisk Tidsskrift 66, Supplement 1, 96 p.

Nystuen, J.P., (ed.) 1989. Rules and recommendations for naming geological units in Norway by the Norwegian Committee on Stratigraphy. Norsk Geologisk Tidsskrift 69, Suppl. 2, 111 p.

Ragnhildstveit, J., Sigmond, E.M.O. \& Tucker, R.D., 1994. Early Proterozoic suprcrustal rocks west of the Mandal-Ustaoset fault zone, Hardangervidda, south Norway. Terra Abstracts, supplement No. 2 to Terra Nova, pp. 15-16.

Richards, F. L., 1998. The structural geology of the Telemark supracrustal suite, South Norway. PhD Thesis, University College Cork, 296 p + 12 appendixes.

Sigmond, E.M.O., 1985. The Mandal-Ustaoset Line, a newly discovered major fault zone in South Norway. NATO ASI Series, Series C: Mathematical and Physical Sciences 158, 323-331

Sigmond, E.M.O., 1998. Geologisk kart over Norge, Berggrunnskart ODDA, M 1:250 000. Norges geologisk undersøkelse, Trondheim.

Sigmond, E.M.O., Gjelle, S.\& Solli, A., 1997. The Rjukan Proterozoic rift basin, its basement and cover, volcanic, and sedimentary infill, and associated intrusions. Norges geologiske undersøkelse, Bulletin 433, 6-7.

Starmer, I.C., 1993. The Sveconorwegian orogeny of southern Norway, relative to deep crustal structures and events in the North Atlantic Proterozoic Supercontinent. Norsk Geologiske Tidsskrift 73, 109-32.

Werenskiold, W., 1910. Om Øst-Telemarken. Norges geologiske undersøkelse, Bulletin 52, 69 p.
Wilson, G., 1961. The tectonic significance of small scale structures, and their importance to the geologists in the field. Annales de la Société de Géologique de Belgique, 84, 423-548.

Wyckoff, D., 1934. Geology of the Mt. Gausta Region in Telemark, Norway. Norsk Geologisk Tidsskrift 13, 172. 